NASA/TM-2007-214926

(453)

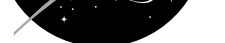

\title{
Mechanical Properties of 17-4PH Stainless Steel Foam Panels
}

S.V. Raj

Glenn Research Center, Cleveland, Ohio

L.J. Ghosn

Ohio Aerospace Institute, Brook Park, Ohio

B.A. Lerch

Glenn Research Center, Cleveland, Ohio

M. Hebsur

Ohio Aerospace Institute, Brook Park, Ohio

L.M. Cosgriff

Cleveland State University, Cleveland, Ohio

J. Fedor

University of Notre Dame, Notre Dame, Indiana 


\section{NASA STI Program . . . in Profile}

Since its founding, NASA has been dedicated to the advancement of aeronautics and space science. The NASA Scientific and Technical Information (STI) program plays a key part in helping NASA maintain this important role.

The NASA STI Program operates under the auspices of the Agency Chief Information Officer. It collects, organizes, provides for archiving, and disseminates NASA's STI. The NASA STI program provides access to the NASA Aeronautics and Space Database and its public interface, the NASA Technical Reports Server, thus providing one of the largest collections of aeronautical and space science STI in the world. Results are published in both non-NASA channels and by NASA in the NASA STI Report Series, which includes the following report types:

- TECHNICAL PUBLICATION. Reports of completed research or a major significant phase of research that present the results of NASA programs and include extensive data or theoretical analysis. Includes compilations of significant scientific and technical data and information deemed to be of continuing reference value. NASA counterpart of peer-reviewed formal professional papers but has less stringent limitations on manuscript length and extent of graphic presentations.

- TECHNICAL MEMORANDUM. Scientific and technical findings that are preliminary or of specialized interest, e.g., quick release reports, working papers, and bibliographies that contain minimal annotation. Does not contain extensive analysis.

- CONTRACTOR REPORT. Scientific and technical findings by NASA-sponsored contractors and grantees.
- CONFERENCE PUBLICATION. Collected papers from scientific and technical conferences, symposia, seminars, or other meetings sponsored or cosponsored by NASA.

- SPECIAL PUBLICATION. Scientific, technical, or historical information from NASA programs, projects, and missions, often concerned with subjects having substantial public interest.

- TECHNICAL TRANSLATION. Englishlanguage translations of foreign scientific and technical material pertinent to NASA's mission.

Specialized services also include creating custom thesauri, building customized databases, organizing and publishing research results.

For more information about the NASA STI program, see the following:

- Access the NASA STI program home page at http://www.sti.nasa.gov

- E-mail your question via the Internet to help@sti.nasa.gov

- Fax your question to the NASA STI Help Desk at 301-621-0134

- Telephone the NASA STI Help Desk at 301-621-0390

- Write to: NASA Center for AeroSpace Information (CASI) 7115 Standard Drive Hanover, MD 21076-1320 
NASA/TM-2007-214926

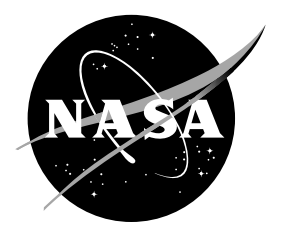

\section{Mechanical Properties of 17-4PH Stainless Steel Foam Panels}

S.V. Raj

Glenn Research Center, Cleveland, Ohio

L.J. Ghosn

Ohio Aerospace Institute, Brook Park, Ohio

B.A. Lerch

Glenn Research Center, Cleveland, Ohio

M. Hebsur

Ohio Aerospace Institute, Brook Park, Ohio

L.M. Cosgriff

Cleveland State University, Cleveland, Ohio

J. Fedor

University of Notre Dame, Notre Dame, Indiana

National Aeronautics and

Space Administration

Glenn Research Center

Cleveland, Ohio 44135 


\section{Acknowledgments}

The authors thank Dr. Brian Fite for providing details of the NASA fan blade design and for his advice during the course of this work, and Dr. Jane Manderscheid for her comments on the paper.

This work was sponsored by the Fundamental Aeronautics Program at the NASA Glenn Research Center.

Level of Review: This material has been technically reviewed by technical management.

Available from

NASA Center for Aerospace Information 7115 Standard Drive

Hanover, MD 21076-1320
National Technical Information Service 5285 Port Royal Road Springfield, VA 22161 


\title{
Mechanical Properties of 17-4PH Stainless Steel Foam Panels
}

\author{
S.V. Raj \\ National Aeronautics and Space Administration \\ Glenn Research Center \\ Cleveland, Ohio 44135 \\ L.J. Ghosn \\ Ohio Aerospace Institute \\ Brook Park, Ohio 44142 \\ B.A. Lerch \\ National Aeronautics and Space Administration \\ Glenn Research Center \\ Cleveland, Ohio 44135 \\ M. Hebsur \\ Ohio Aerospace Institute \\ Brook Park, Ohio 44142 \\ L.M. Cosgriff \\ Cleveland State University \\ Cleveland, Ohio 44115 \\ J. Fedor \\ University of Notre Dame \\ Notre Dame, Indiana 46556
}

\begin{abstract}
Rectangular 17-4 PH stainless steel sandwiched foam panels were fabricated using a commercial manufacturing technique by brazing two sheets to a foam core. Microstructural observations and ultrasonic nondestructive evaluation of the panels revealed large variations in the quality of the brazed areas from one panel to the next as well as within the same panel. Shear tests conducted on specimens machined from the panels exhibited failures either in the brazed region or in the foam core for the poorly brazed and well-brazed samples, respectively. Compression tests were conducted on the foam cores to evaluate their elastic and plastic deformation behavior. These data were compared with published data on polymeric and metallic foams, and with theoretical deformation models proposed for open cell foams.
\end{abstract}

\section{Introduction}

The quest for inexpensive, low density and high performance materials in the design of aircraft engine fan and rotorcraft propeller blades poses immense challenges to materials and structural design engineers. Traditionally, these components have been fabricated with lightweight titanium alloys, and polymeric composite materials (refs. 1 and 2). For example, fan blades in General Electric Aircraft Engines (GEAE) current GE 90 series engines consist of carbon reinforced epoxy composites reinforced by titanium across their leading edges for improved resistance to impact and foreign object damage (FOD) and on their tip caps for improved wear resistance (refs. 2 and 3). These fan blades weigh between 13 and $23 \mathrm{~kg}$ with each engine requiring 22 fan blades (ref. 3 ). 
Despite their proven history, current fan blade materials and designs suffer from high design and manufacturing costs, which add to the overall cost of the aircraft and rotorcraft vehicles. Recent advances in cellular theory and manufacturing techniques have created a renewed interest in the application of metallic foams in the fabrication of engineering components (refs. 4 to 10). Foams, which fall under the general category of cellular materials, provide several advantages to the designer due to their diverse multifunctional characteristics and uses (ref. 8). For example, honeycomb I-beam structures (ref. 11) and lightweight sound-absorbing honeycomb launch vehicle structures (ref. 12) have been proposed in the past. Similarly, Boeing Corporation has considered the use of aluminum sandwiched foam cores for helicopter tail booms (ref. 8). In particular, metallic foams possess low density, energy absorption and vibration dampening properties, and an ability to be fabricated with curvatures into three-dimensional structures. These characteristics make them especially attractive for designing fan blades out of cheap and common materials, such as high strength and high toughness precipitation-hardened (PH) stainless steels. Unlike honeycomb structures, which are anisotropic in nature, components with a foam core are likely to exhibit isotropic properties.

The present research was conceived under NASA's ULTRASAFE Project to demonstrate the feasibility of designing and fabricating fan and propeller blades using a combination of well known high strength, high toughness aerospace grade stainless steel, such as 17-4 PH, and commercially available foam processing technology. The proposed blade architecture is a lightweight sandwich construction made up of thin contoured solid face sheets either brazed or solid-state diffusion bonded to a space-filling metallic foam core (fig. 1). The embedding of a foam core between two face sheets considerably increases the stiffness of the sandwich blade. Details of preliminary design analyses suggest that the concept is not only feasible but also provides definite weight and stiffness advantages over solid Ti- $6 \% \mathrm{Al}-4 \% \mathrm{~V}$ fan blades (ref. 13).

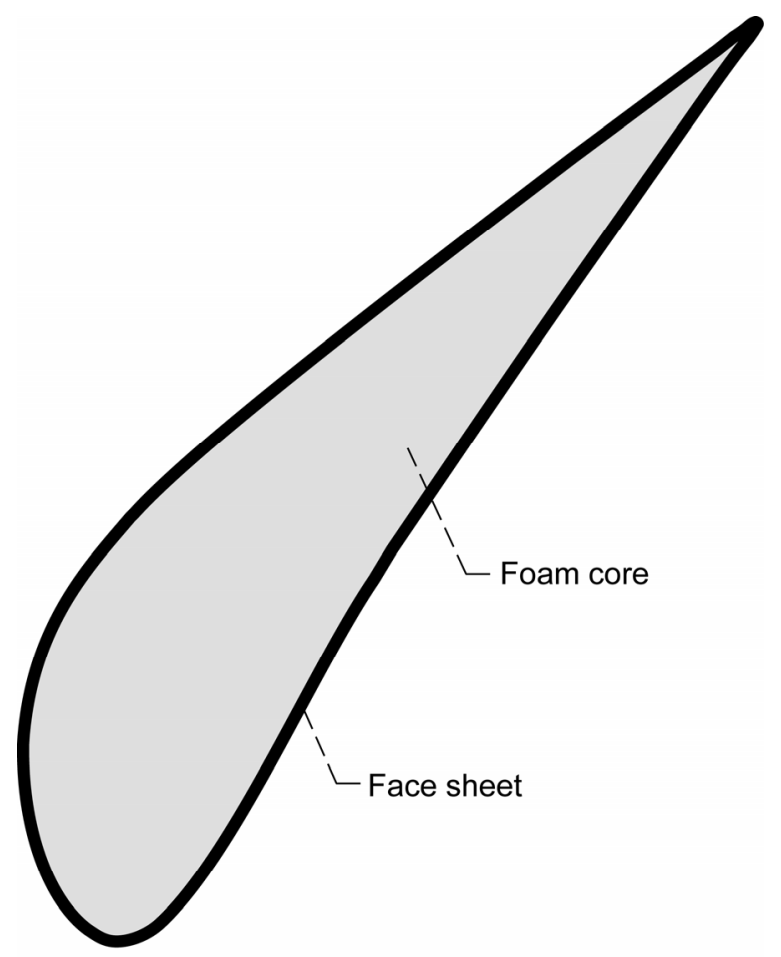

Figure 1.- Schematic of a sandwiched foam fan blade showing the foam core enclosed by the face sheet skin. 
The use of aerospace grade precipitation hardened stainless steel 17-4 PH for fabricating fan and propeller blades is advantageous from several points of view. First, it is commonly utilized in the fabrication of many aircraft components (e.g., landing gear) due to its attractive combination of high tensile and impact strengths and fracture toughness. Second, it is corrosion resistant to ambient and marine environments. Third, the relative ease with which metallic foam cores can be fabricated from 17-4 PH powder using current manufacturing techniques makes it amenable to scale-up and mass production (ref. 14). Fourth, steel sheets are significantly cheaper than those of titanium sheets by at least a factor of 13 and as much as a factor of 167. Clearly, the economic advantages of replacing the titanium blades with less expensive stainless steel blades are very compelling and immensely beneficial in reducing the cost of aircraft engines and rotorcraft blades.

The success of implementing the 17-4PH stainless steel foam fan and propeller blade design is largely dependent on optimizing the manufacturing technology to fabricate panels with acceptable and reproducible microstructures and mechanical properties. The objectives of this paper are to report on the mechanical properties of a first batch of 17-4PH stainless steel foam panels produced by PORVAIR Inc., Hendersonville, North Carolina.

\section{Experimental Materials, Fabrication Methods and Test Procedures}

\subsection{Sandwich Foam Panel Fabrication}

Ten rectangular 17-4PH stainless steel sandwiched foam panels were fabricated by PORVAIR Inc., Hendersonville, North Carolina. The fabrication of these initial batches of panels involved several steps. First, 17-4PH foam cores with nominal relative densities, $\rho_{c} / \rho_{s}$ of $6 \%(3$ pores $/ \mathrm{mm}),{ }^{1} 8 \%(1 \mathrm{pore} / \mathrm{mm})$, $10 \%(1 \mathrm{pore} / \mathrm{mm})$ and $13 \%(1 \mathrm{pore} / \mathrm{mm})$, where $\rho_{c}$ and $\rho_{s}$ are the densities of the foam core and solid material, respectively, were produced using a proprietary powder metallurgy process (ref. 14). Second, two wrought 17-4PH face sheets $1.6 \mathrm{~mm}$ thick were brazed on to the foam core using either BNi-6, BAg13a or BAg-19 brazing alloys to produce sandwiched foam panels of dimensions approximately 254 by 152 by $13.4 \mathrm{~mm}$ with a $10.2 \mathrm{~mm}$ thick foam core. Specimens foam cores with $\rho_{c} / \rho_{s}$ of $6 \%$ were fabricated using BNi-6 as the brazing alloy, whereas those with $\rho_{c} / \rho_{s}$ of 8,10 and $13 \%$ were brazed with either BAg13 or BAg-19 brazing alloys. Third, the sandwich foam panels were heat treated according to SAE specifications AMS 5355F (ref. 16). The panels were first solution annealed at $1310 \mathrm{~K}$ for $1 \mathrm{~h}$ followed by an aging treatment at $825 \mathrm{~K}$ for $1.5 \mathrm{~h}$ under argon.

\subsection{Nondestructive Evaluation of Sandwiched Foam}

The foam panels were nondestructively evaluated by ultrasonic c-scan imaging and spectroscopy techniques to identify defects primarily in the brazed joint between the face sheet and the foam core (ref. 17). Ultrasonic spectroscopy has been demonstrated to be effective in detecting delamination and degradation of composite materials as well as flaws, cracks and corrosion in multiple layered structures (refs. 18 to 20). An integrated approach combining observations made by both these nondestructive evaluation (NDE) techniques was utilized to evaluate the panels. Owing to the fact that the brazed region and the foam core attenuated the sound waves extremely well, the measurements were first conducted by placing the transducers, first on one face and then on the opposite face, referred to as "front" and the "back", respectively, in this paper. Details of the experimental procedures are described elsewhere (ref. 13 and 17), and only a brief description is provided here.

The ultrasonic c-scan images were acquired with a single $10 \mathrm{MHz}$ transducer in a pulse-echo mode of transmission with the panel immersed in a tank of water. The images produced represent a map of the peak amplitude in a gated region of an ultrasonic waveform after it has traversed the material. These

\footnotetext{
${ }^{1}$ The relative densities and pore/mm values reported here correspond to the data supplied by the manufacturer. The pore/mm value corresponds to the polyurethane foam starting material.
} 
images were used to distinguish the well-bonded regions from the poorly brazed areas of sandwich foam panels, which were then corroborated with ultrasonic spectroscopy before and after machining the shear test specimens.

The ultrasonic spectroscopic measurements were conducted using two transducers coupled to the same face of the panel with a gel couplant. A commercially available system equipped with a digital processing oscilloscope, amplifier, digital-to-analog converter, and computer software was employed for processing the input and output signals (ref. 18). The software was programmed to generate a continuous swept-frequency acoustic wave and acquire the corresponding response of the test specimen.

Measurements were conducted on the sandwiched foam panels before and after they were sectioned into shear test specimens. A digital input waveform generated by an ultrasonic pulsating source was transmitted to the face sheet by an ultrasonic transducer. The ultrasonic time domain response of the reflected wave was received by a second transducer. The spectra from the front and back faces of the panel were compared in a single plot to determine the quality of the brazed joints at these locations. Two $5 \mathrm{MHz}$ medium damped direct contact transducers were coupled to the surface of each panel in these measurements and the frequency range of each swept sine waveform was between 1 and $5 \mathrm{MHz}$ in order to excite the fundamental ultrasonic resonance of the face sheet based on the known thickness and ultrasonic velocity of the material. In this particular study, the fundamental resonant frequency is produced when the face sheet is poorly bonded to the metallic foam core.

\subsection{Microscopy and Mechanical Test Procedures}

Microstructural observations on sections of the sandwiched foam panels were conducted using optical and scanning electron microscopy (SEM). Additional information on the quality of the foams as well as the brazed joints was obtained by back scattered electron (BSE) imaging techniques and energy dispersive spectroscopy (EDS).

Specimens were machined from sandwiched foam core panels as well as from the stainless steel foams for mechanical property determination. Compressive tests were conducted on the 17-4PH foam cores in a servohydraulic machine at a crosshead displacement rate of $0.043 \mathrm{~mm} \mathrm{~s}^{-1}$, where the foam was crushed between a set of platens. The dimensions of the 17-4PH sandwiched foam compression specimens in these tests were 25.4 by 25.4 by $9.9 \mathrm{~mm}$. The relative displacement of the upper and lower platens was precisely measured by a contact extensometer, while the load was measured using a load cell. The load and displacement data were converted to engineering stress and engineering strain values, respectively.

Shear tests were conducted in a double-pinned clevis following a procedure similar to that recommended in ASTM C273 at a cross-head speed of $0.043 \mathrm{~mm} \mathrm{~s}^{-1}$ to test the integrity of the brazed joints (fig. 2(a)). The dimensions of these test specimens were 152.4 by 25.4 by $13.4 \mathrm{~mm}$ (fig. 2(b)). The thickness of the foam core was $10.2 \mathrm{~mm}$. As mentioned earlier, these specimens were machined from regions of the sandwiched foam panels containing both good and poor brazed joints, which were examined by ultrasonic spectroscopy before and after testing. The original specimen designs had two notches machined through one face sheet and through the core thickness as shown in fig. 2(b) to allow shear stresses to develop at the brazed joints. It was observed that this specimen design frequently resulted in failure of the brazed joint. Thus, the specimen design was modified by machining a circumferential notch $25.4 \mathrm{~mm}$ long, $6.35 \mathrm{~mm}$ wide and $1.6 \mathrm{~mm}$ high at the mid section of the foam core (fig. 2(c)). This modified design ensured that the specimen would always fail in the foam core rather than at the brazed joints, thereby enabling the shear strength of the foam to be reliably measured. 

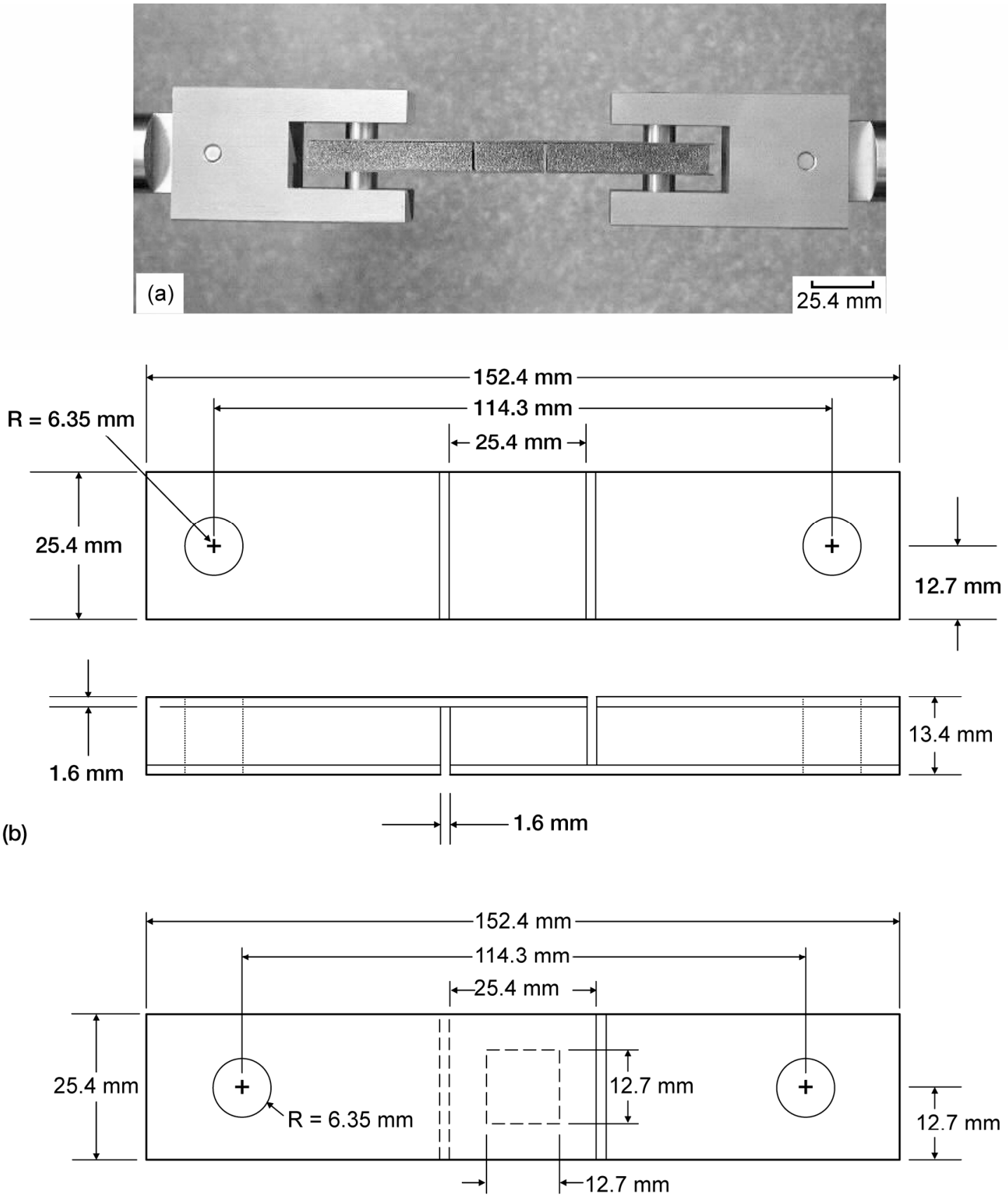

(c)

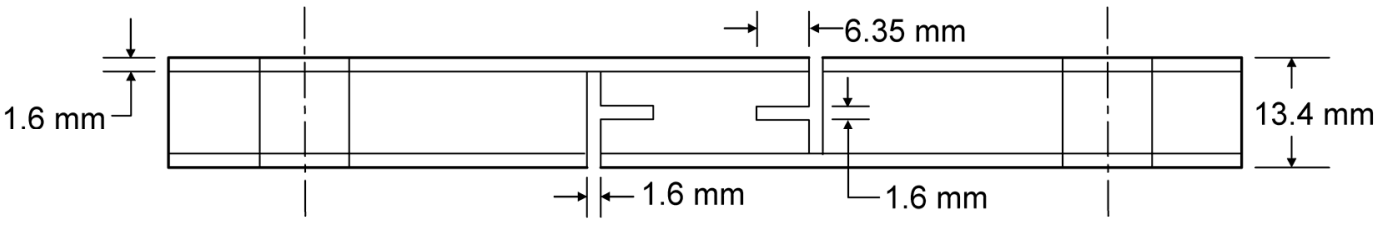

Figure 2.-(a) Photograph of a shear specimen on the test frame prior to testing. (b) Typical dimensions of (b) unnotched and (c) circumferentially notched shear test specimens sectioned from the sandwiched foam panel. All dimensions in $\mathrm{mm}$. 


\section{Results and Discussion}

\subsection{Microstructural Observations of the As-Received Foam Panels}

Figure 3(a) shows a macrograph of the cross-section of a 17-4 PH sandwiched panel while figure 3(b) and (c) show the scanning electron micrographs of a section of the brazed interface. These observations revealed that the foam cores consisted of a mixture of closed and open cells with a qualitative predominance of the latter. Microstructural observations of the brazed regions of the 17-4 PH (fig. 3(b)) revealed that the quality of the brazing was non-uniform. Although some regions showed that the brazing alloy had penetrated the foam to provide a reasonable bond with the face sheet, there were many regions where there was little or no penetration of the brazing alloy leading to a poor or nonexistent bonding with the face sheet (fig. 3(c)). Clearly, this lack of uniform brazing throughout the entire cross-section of the sandwiched foam panels is of major concern.

Cracks were observed in the BSE images of the polished cross-sections of the sandwiched panel containing sizeable brazed regions several hundred microns in length (fig. 4(a) and (b)). As depicted in figure 4(a), these cracks generally originated at points close to the face sheet but within the brazed region and propagated towards the unbrazed foam core. Low magnification electron dispersive spectroscopic observations of the brazed region and the foam ligaments showed no evidence of phosphorous diffusion from the brazing alloy to the stainless steel (fig. 5(a) to (c)). However, high magnification observations of the braze-foam interface regions revealed dark and light areas in the BSE images (fig. 6(a) and (b)), where the light areas contained lower amounts of $\mathrm{Cr}$ and $\mathrm{P}$ (fig. 6(c)) than the dark regions (fig. 6(d)). Optical micrographs of polished cross-sections of the foam cores showed extensive ligament failure and small shrinkage porosity within many of the individual ligaments.

\subsection{Ultrasonic Observations of the As-Received Sandwich Foam Panels}

Ultrasonic c-scan images from the front and back faces of the 17-4PH sandwiched panels were consistent with the microstructural observations (ref. 13). Figures 7 to 9 show the ultrasonic c-scan images, the ultrasonic spectral responses and the corresponding microstructural observations of shear test specimens, A, B, C, and D, precisely machined from different areas of a sandwiched panel, respectively. In general, there was a close correspondence between the ultrasonic c-scan images (fig. 7(a) and (b)), ultrasonic spectroscopy spectra (fig. 8(a) to (c)) and optical micrographs of the side cross-sections of the test specimens (fig. 9(a) to (c)). The dark and light areas in fig. 7 correspond to signals reflected back from the well-brazed and unbrazed regions of the panel, respectively. The ultrasonic signal was attenuated at the well-brazed regions so that the ultrasonic waves did not return to the transducer. Thus, specimens $\mathrm{A}$ and $\mathrm{B}$ with a larger density of light areas compared to specimens $\mathrm{C}$ and $\mathrm{D}$ generally indicate poor to fair bonding of the face sheet to the foam core, whereas the c-scan images from specimens $\mathrm{C}$ and $\mathrm{D}$ suggest relatively well bonded interfaces.

Figure 8(a) to (c) compare the ultrasonic frequency spectra from the front and back of specimens A, $\mathrm{B}$, and $\mathrm{C}$ corresponding to areas exhibiting different qualities of bonding between the face sheets and the foam core. The spectrum for region $\mathrm{D}$, which is not shown here, was similar to figure 8(c). The magnitudes of the peaks in the spectra are indicative of the degree of bonding between the face sheets and the foam core. Large peaks observed in the ultrasonic spectra correspond to areas of poor bonding since the ultrasonic waves are reflected by the back face of the front sheet rather than being attenuated by the foam core (fig. 8(a)). Correspondingly, smaller peaks barely distinguishable from background noise indicate well-bonded regions of the sandwiched foam panel since the signal is attenuated by the foam core (fig. 8(c)). Once again, these spectral responses are consistent with the c-scan images shown in figure 7(a) to $(\mathrm{c})$. 

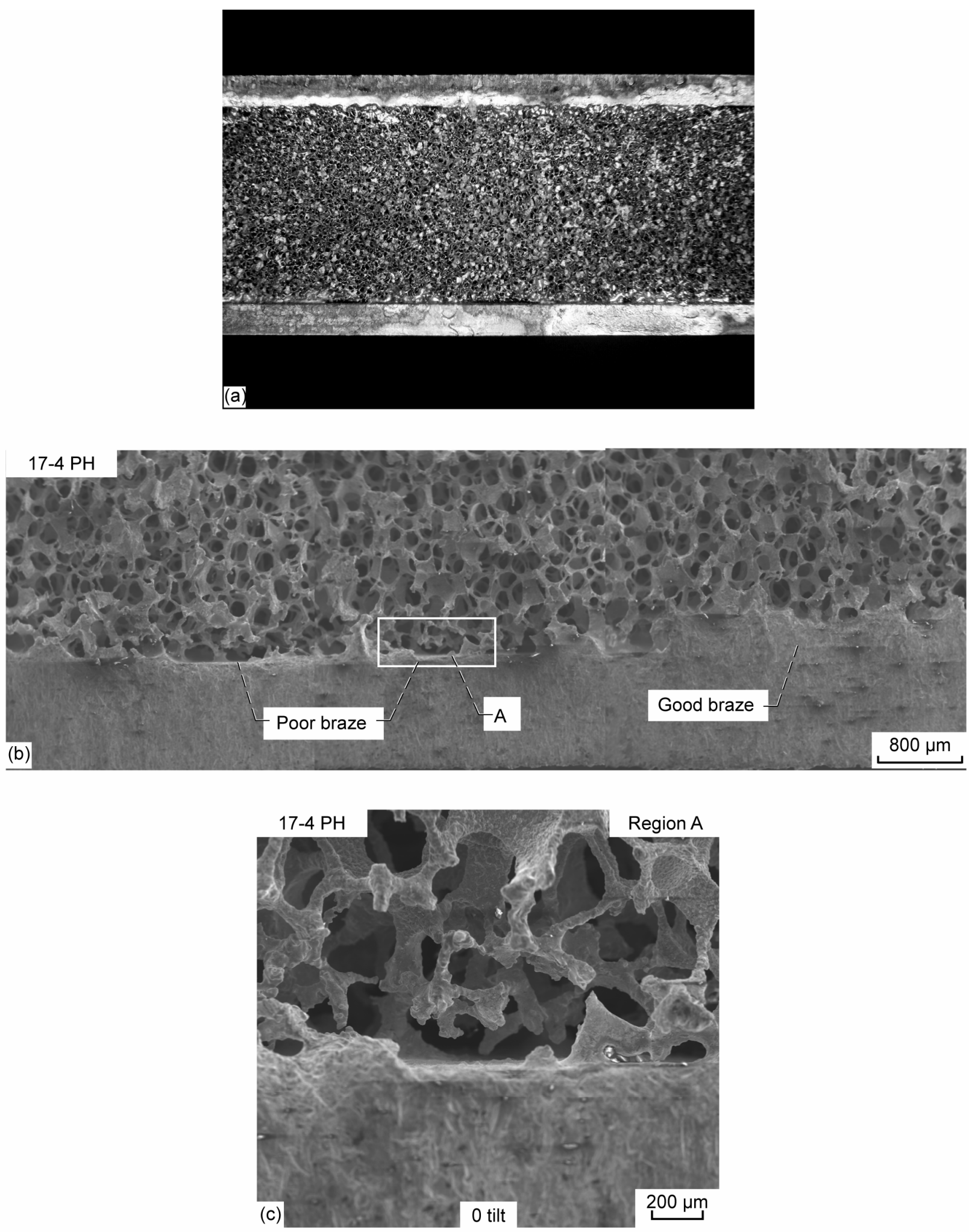

Figure 3.-(a) Optical macrograph of the cross-section of a 17-4 PH sandwiched foam panel showing the foam core and face sheets.(b) Scanning electron micrographs of the brazed regions of (a) 17-4 PH panel. (c) High magnification scanning electron micrographs of the brazed region A shown in (b). 

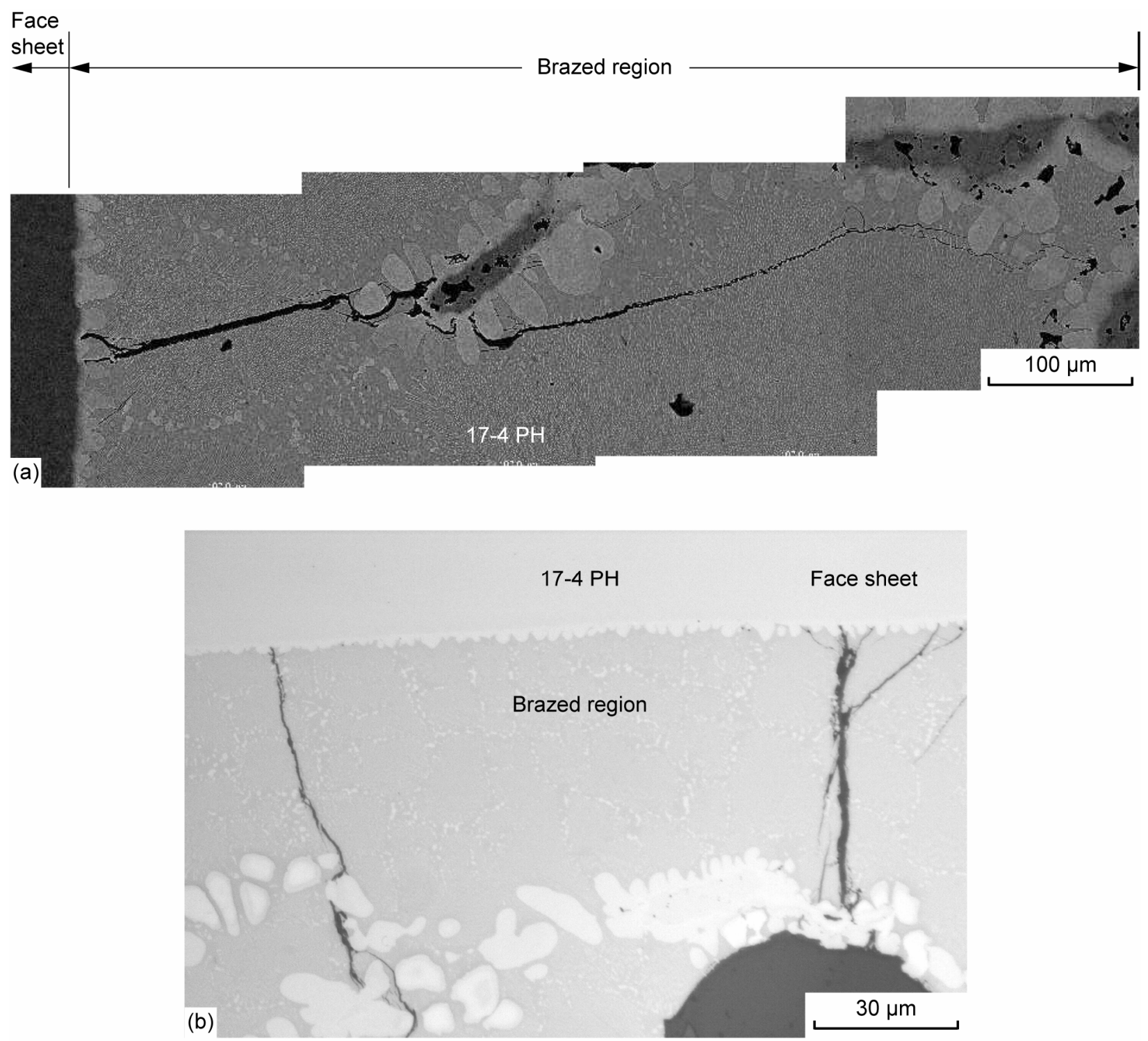

Figure 4.-(a) and (b) High magnification back scattered electron micrographs of the brazed zone in a polished cross-section of a 17-4 PH sandwiched foam panel showing cracks. 


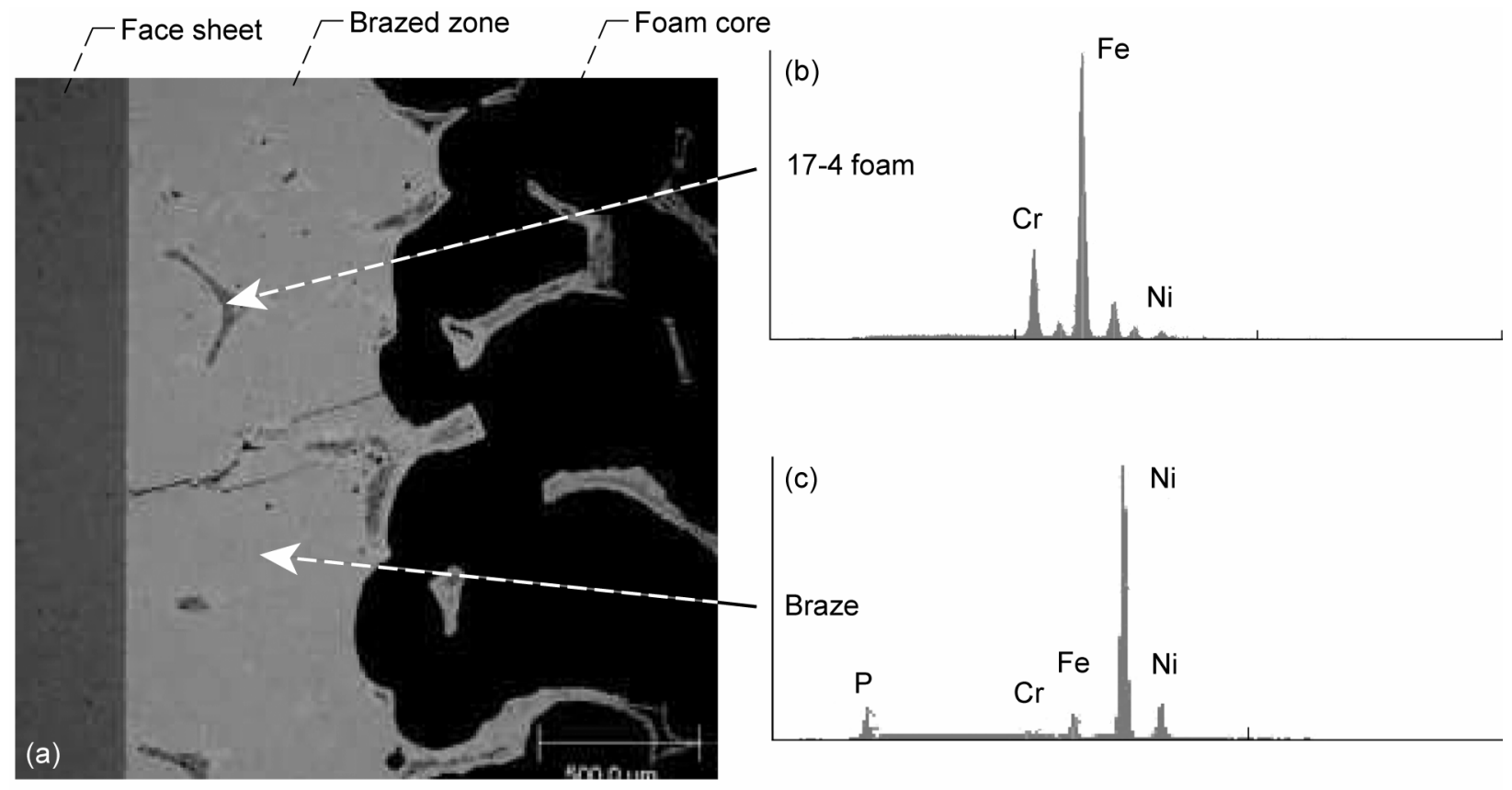

Figure 5.-(a) Low magnification back scattered electron micrograph and (b) and (c) energy dispersive spectra of (b) the foam and (c) the braze alloy in the brazed zone shown in (a) of a polished cross-section a 17-4 PH sandwiched foam panel. 

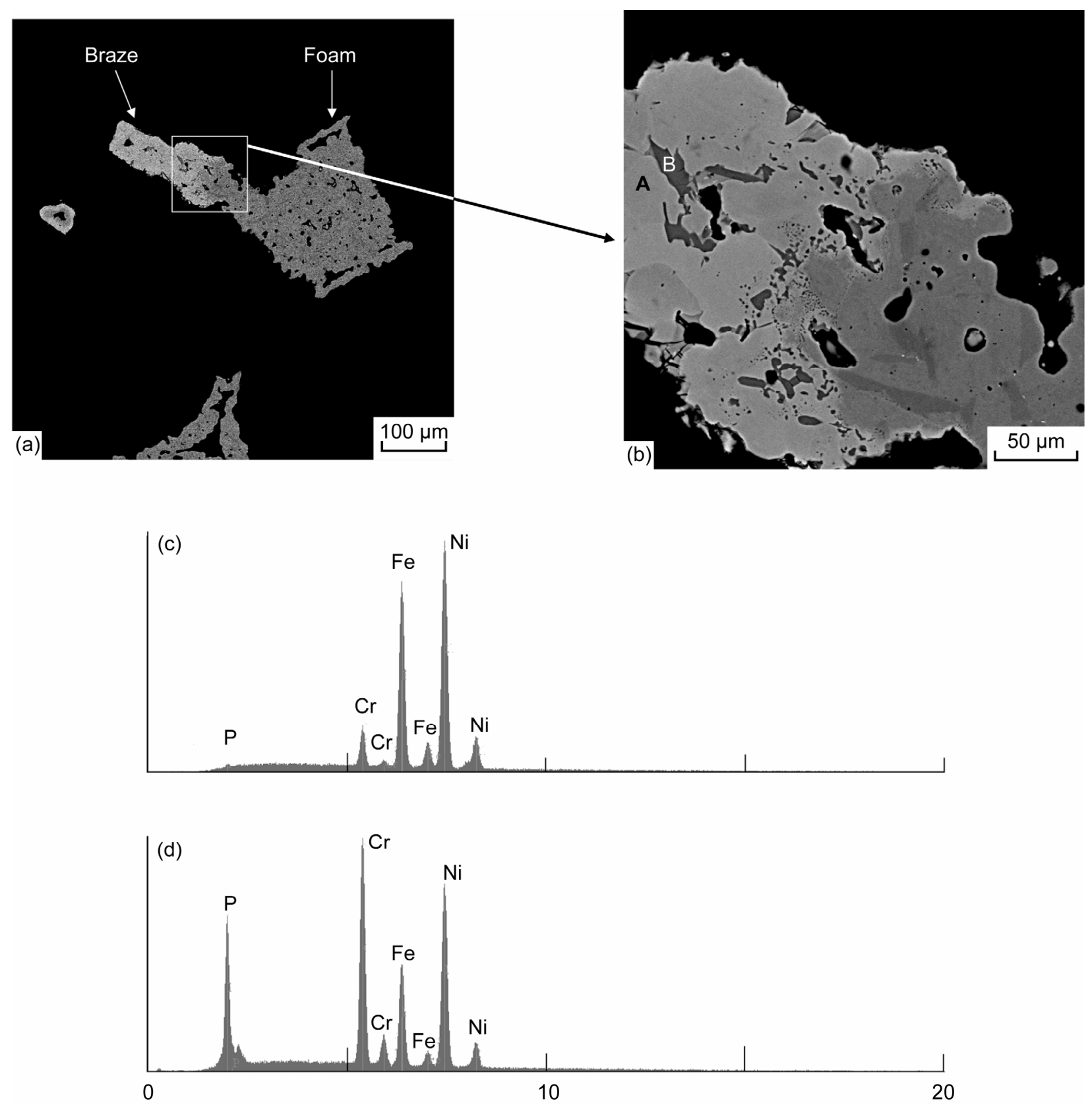

Figure 6.-(a) and (b) High magnification back scattered electron micrographs of a polished cross-section of the brazed zone of a 17-4 PH sandwiched foam panel showing details of the braze and foam. Energy dispersive spectra showing the compositions of (c) region $A$ and $(d)$ region $B$ shown in figure $6(b)$. 


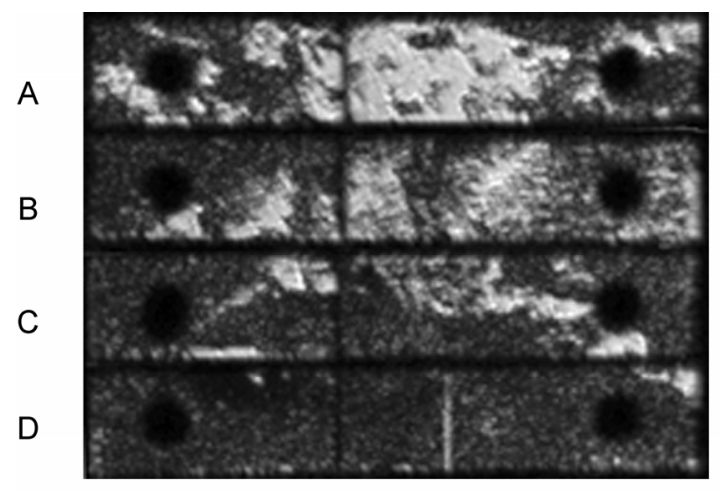

(a)

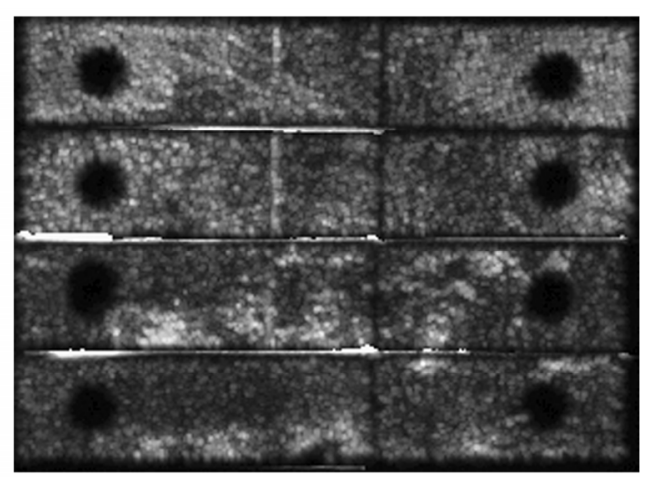

(b)

Figure 7.-Ultrasonic c-scan images of the (a) front and (b) back surfaces of the shear test specimens machined from four regions $A, B, C$ and $D$ of a sandwiched $17-4 \mathrm{PH}$ panel.
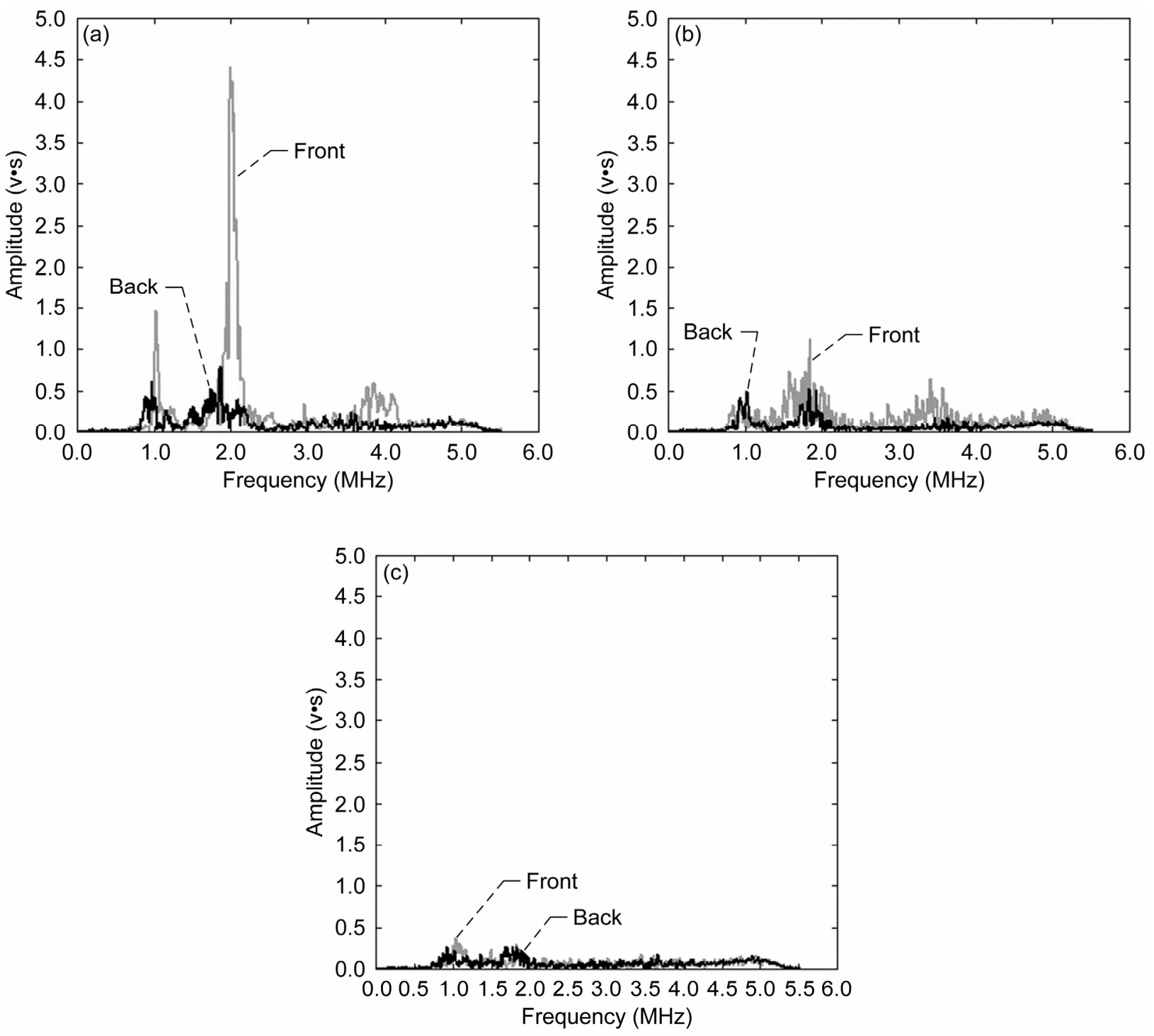

Figure 8.-Ultrasonic spectral responses from the shear test specimens machined from regions $A, B$ and $C$ prior to testing. (a) Frequency spectra from shear specimen A; (b) frequency spectra from shear specimen B; and (c) frequency spectra from shear specimen $\mathrm{C}$. 

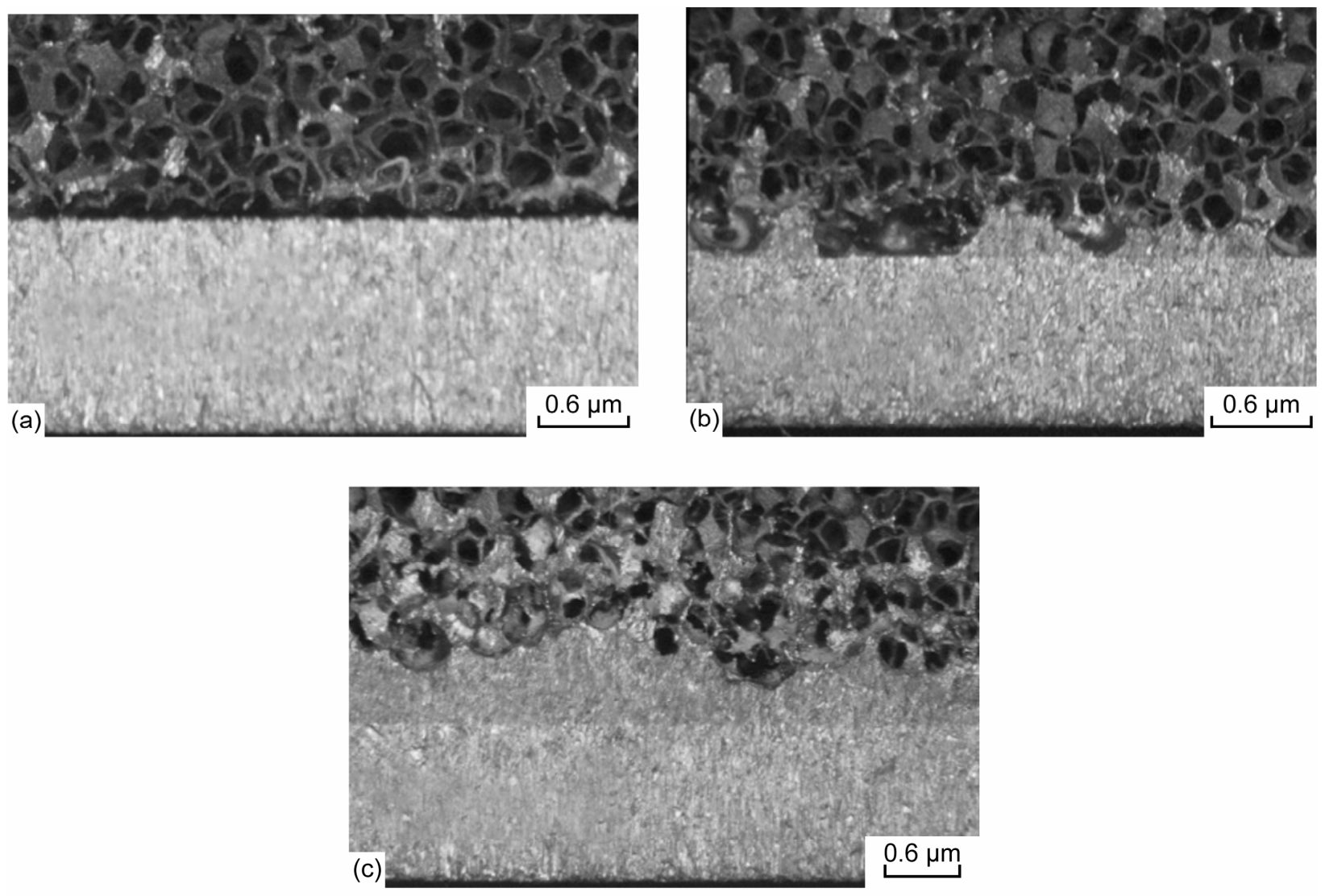

Figure 9.-Optical micrographs of the side cross-sections of the shear test specimens machined from regions (a) A, (b) B and (c) D shown indicating that region A was poorly bonded while region $D$ was well-bonded.

Optical micrographs of the cross-sections of specimens A, B, and D are also consistent with the ultrasonic c-scan and ultrasonic spectral observations (fig. 9(a) to (c)). In this case, figure 9(a) shows the microstructure of a foam/face sheet interface of specimen A, where the brazed zone is essentially nonexistent indicating poor bonding. A brazed zone of non-uniform thickness is visible in specimen B corresponding to the condition of a fair interface bonded region (fig. 9(b)). In contrast, specimen D shows a well-bonded interface with a significant amount of the brazed zone in evidence (fig. 9(c)).

\subsection{Compressive Stress-Strain Curves}

Compression stress-strain curves were generated on the sandwiched foam 17-4 PH stainless steels specimens to evaluate current processing techniques with theoretical predictions. Figure 10(a) shows the compressive engineering stress, $\sigma_{c e}$, plotted against engineering strain, $\varepsilon$, for two specimens with $\rho_{c} / \rho_{s} \approx$ $6 \%$, where the thickness of the entire sandwich (i.e., $\left(2 t+t_{c}\right)$, where $t$ and $t_{c}$ are the thicknesses of the face sheet and foam core, respectively) was assumed to be the gage length. ${ }^{2}$ Also shown in the figure is the expected yield strength of an ideal foam core without manufacturing defects given by equation (1) formulated to describe the compiled data without a density correction (ref. 4)

\footnotetext{
${ }^{2}$ Alternatively, the thickness of the foam core could have been assumed to be the gauge length if all the deformation occurs in this region. The gauge length $\left(2 t+t_{c}\right)$ takes into account the possibility of any deformation of the brazed regions and face sheets.
} 


$$
\frac{\sigma_{y c}}{\sigma_{y s}} \approx 0.3\left(\frac{\rho_{c}}{\rho_{s}}\right)^{3 / 2}
$$

where $\sigma_{y c}$ and $\sigma_{y s}$ are the yield stresses of the foam core and solid material, respectively. The magnitude of $\sigma_{y s}$ for wrought $17-4 \mathrm{PH}$ heat treated in the H-1025 condition was assumed to be $1172 \mathrm{MPa}$ (ref. 21). The specimens were periodically unloaded and re-loaded at different values of engineering strain in order to determine the Young's moduli at different values of strain, where these measurements were used to give an indication of the extent of foam densification during deformation. The elastic modulus was determined from the slope of a linear regression equation fitted to the linear region of the unloading portion of the $\sigma_{c e}-\varepsilon$ curves.
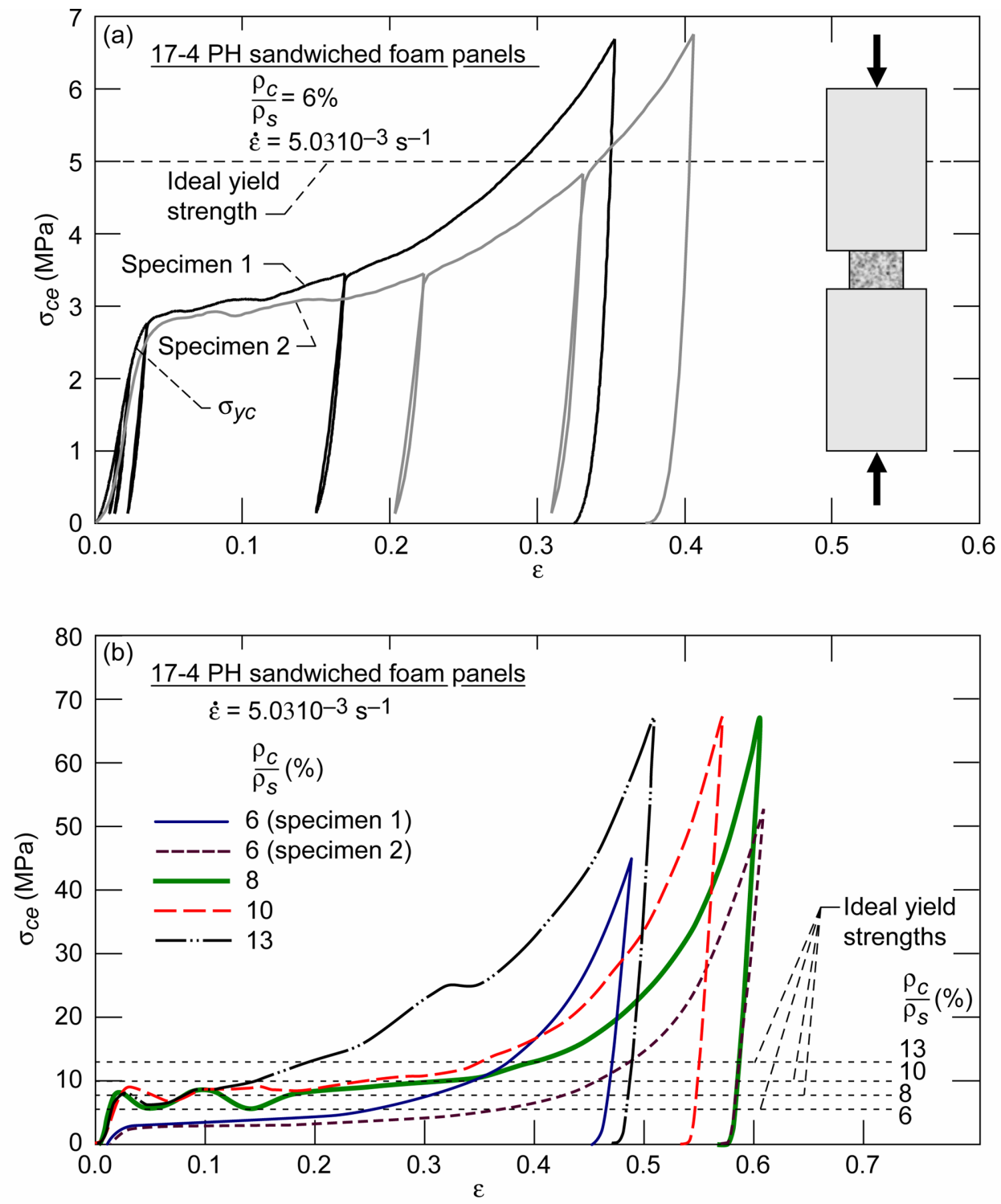

Figure 10.-(a) Compressive engineering stress versus engineering strain for two 17-4 PH sandwiched foam specimens with $\rho_{c} / \rho_{s} \approx 6 \%$ deformed at room temperature under an initial strain rate of about $5 \times 10^{-3} \mathrm{~s}^{-1}$. (b) Comparison of the engineering stress versus engineering strain curves for $17-4 \mathrm{PH}$ sandwiched foam specimens with $\rho_{c} / \rho_{s} \approx 6-13 \%$ deformed at room temperature under an initial strain rate of about $5 \times 10^{-3} \mathrm{~s}^{-1}$. 
An examination of figure 10(a) reveals the classical three stages of deformation reported for other foam materials (refs. 4 and 7). The initial linear elastic region is followed by a near plateau deformation regime, where $\sigma_{c e}$ increases gradually with increasing $\varepsilon$, as the foam begins to plastically collapse and finally by a densification third stage, where the engineering stress increases steeply with increasing $\varepsilon$ as the foam densifies into a solid. The duplicate stress-strain curves are similar and show a close correspondence in their reproducibility. The experimental yield strength of the foam, $\sigma_{y c}$, which is identified with the plastic collapse stress, $\sigma^{*}{ }_{\mathrm{pl}}$ is about $2.5 \mathrm{MPa}$. This value is about half that calculated using equation (1). The latter stress is defined as the magnitude of $\sigma_{\mathrm{ce}}$ at the point of transition from the linear elastic regime to the plastic collapse region i.e. $\sigma^{*}{ }_{e l}=\sigma_{p l}^{*}$ at $\varepsilon=\varepsilon_{c e}$, where $\sigma_{e l}^{*}$ is the maximum elastic stress prior to plastic collapse and $\varepsilon_{c e}$ is the critical compression strain at which the foam begins to collapse. The 17-4PH foam core exhibits a significantly pronounced second stage of deformation, which indicates that it has superior energy absorption characteristics in the predensification regime.

Figure 10(b) compares the effect of $\rho_{c} / \rho_{s}$ on the nature of the stress-strain curves for $6 \% \leq \rho_{c} / \rho_{s} \leq$ $13 \%$. Once again, the broken horizontal lines represent the ideal yield strength of the foams as given by equation (1). With the exception of the specimen for which $\rho_{c} / \rho_{s} \approx 6 \%$, all other specimens exhibit similar magnitudes of $\sigma^{*}$ pl independent of $\rho_{c} / \rho_{s}$ although the plateau strains generally increase with decreasing values of $\rho_{c} / \rho_{s}$. Thus, the onset of plastic strain at which the specimens begin to densify decreases as $\rho_{c} / \rho_{s}$ increases. Interestingly, these specimens show some mechanical instability in the plateau regime presumably because of a periodic collapse of the cell walls due to buckling under compressive loading. In contrast to the foam specimens with $\rho_{c} / \rho_{s} \geq 8 \%$ for which there appears to be a similar trend in mechanical behavior, the two specimens with $\rho_{c} / \rho_{s} \approx 6 \%$ exhibit significantly lower and almost reproducible values of the plateau stress. The corresponding plateau strains are relatively large varying approximately between 20 and $30 \%$. The magnitudes of the densification strains, $\varepsilon_{D}$, are significantly different for these two specimens presumably due to variations in thickness of the cell walls and their microstructural integrity.

Although the precise reason for the observed differences in the mechanical behavior of these stainless steel foams is still unclear, two possibilities exist. First, the lower strengths of the two specimens with $\rho_{c} / \rho_{s} \approx 6 \%$ is consistent with literature data, where it has been demonstrated that the normalized yield strength of metallic and polymeric foams increase with increasing $\rho_{c} / \rho_{s}$ in accordance with equation (1) (ref. 4). However, this explanation does not account for the fact that the observed yield strengths of foam with $\rho_{c} / \rho_{s} \approx 8-13 \%$ are essentially independent of $\rho_{c} / \rho_{s}$ (fig. 10(b)). Second, since the foams with $\rho_{c} / \rho_{s} \approx$ $6 \%$ exhibited a larger amount of shrinkage porosity in their cell walls (e.g., fig. 6(b)) (ref. 13) than those with $\rho_{c} / \rho_{s} \approx 8-13 \%$ (ref. 22), it is possible that their lower yield strengths can be attributed to the presence of these microstructural defects.

\subsection{Shear Tests}

Double notched shear tests were performed on specimens A, B, C and D shown in figure 11 with $\rho_{c} / \rho_{s} \approx 6 \%$ to determine the strength of the brazed joints using the specimen design illustrated in figure 2(b). Table 1 tabulates the shear strengths, $\tau_{s}$, the average shear modulus, $G$, and the failure modes for the four 17-4 PH specimens. The shear modulus of the solid material is also given for comparison (ref. 23). An examination of Table 1 shows that the shear strengths for specimens machined from regions $\mathrm{C}$ and $\mathrm{D}$ were higher than specimens A and B by a factor of $\sim 3$. Similarly, the shear moduli are about 1.2 times higher for specimens $\mathrm{C}$ and D compared to specimens A and B. These results are consistent with the earlier reported ultrasonic observations on the integrity of the bonding between the face sheet and the foam core in the untested material. 


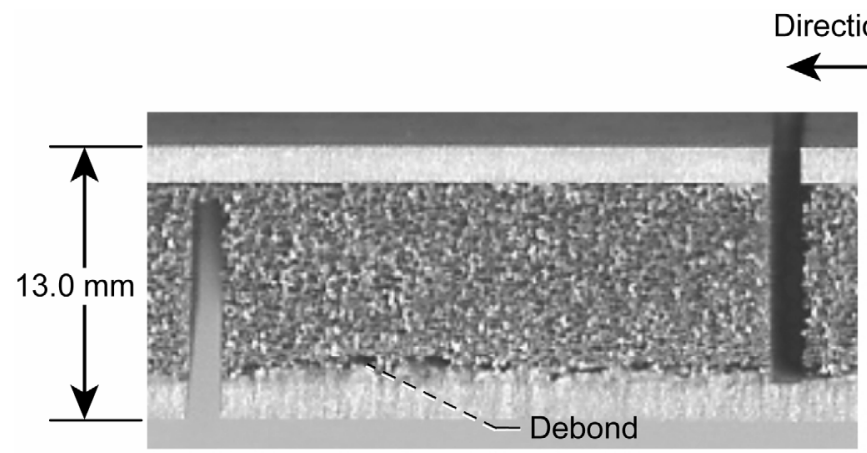

(a)

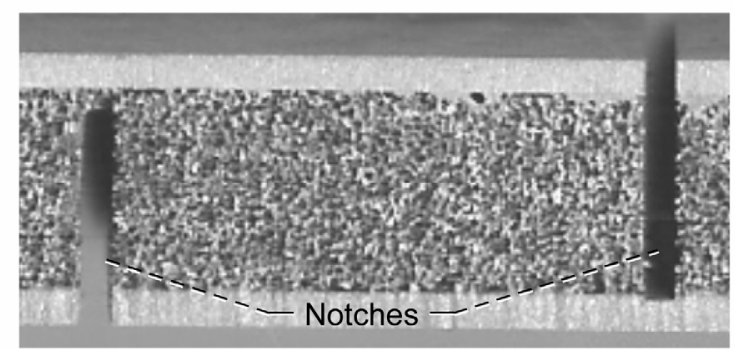

(c)

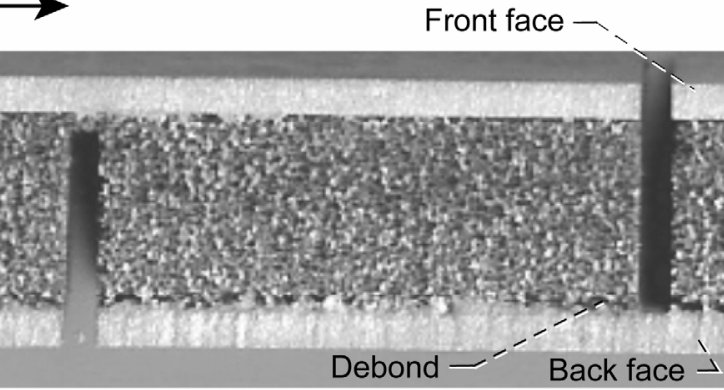

(b)

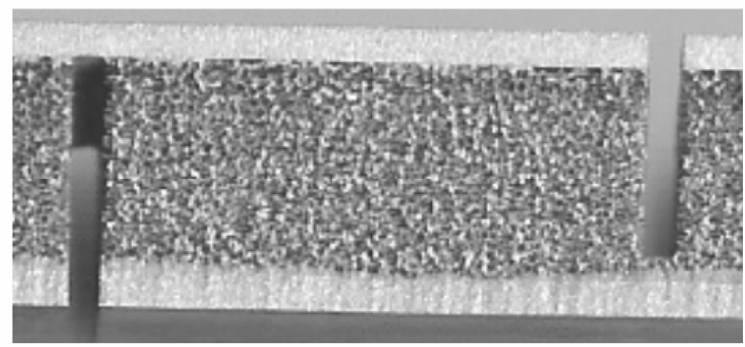

(d)

Figure 11.-Optical macrographs of the side cross-sections of the gauge regions of the shear test specimens machined from the four regions A, B, C and D. (a) Region A; (b) Region B; (c) Region C; and (d) Region D. The specimen design is shown in figure $2(b)$.

TABLE 1.-SHEAR TEST DATA FOR 17-4PH SANDWICHED FOAM SPECIMENS.

\begin{tabular}{|c|c|c|c|}
\hline $\begin{array}{c}\text { Specimen } \\
\text { I.D. }\end{array}$ & $\begin{array}{c}\mathrm{G} \\
(\mathrm{MPa})\end{array}$ & $\begin{array}{c}\tau_{\mathrm{s}} \\
(\mathrm{MPa})\end{array}$ & Failure mode \\
\hline A & 16.3 & 0.69 & Bond line \\
\hline B & 18.6 & 0.95 & Bond line \\
\hline C & 21.1 & 2.40 & Core \\
\hline D & 21.3 & 2.00 & Core \\
\hline Solid & 77,240 (ref. 23) & ---- & ------- \\
\hline
\end{tabular}

Optical macrographs of the failed specimens revealed vastly different failure morphologies between the poorly bonded and the stronger bonded specimens (fig. 12 (a) to (d)). Although the ultrasonic c-scan images revealed that the quality of brazing was poorer on the front faces of specimens A and B (fig. 7(a)) when compared to the back face (fig. 7(b)), these samples failed unexpectedly along or close to the bond line at their rear faces (fig. 12(a) and (b)). However, the fact that the rear faces of these specimens contained voids and cracks prior to testing (fig. 11(a) and (b)) suggests that these defects were primarily responsible for the failure of these samples rather than the debonding of the poorly brazed regions on their front faces. In contrast, specimens $\mathrm{C}$ and $\mathrm{D}$ for which the ultrasonic c-scan images revealed that the qualities of the brazed joints were vastly better than similar observation on specimens A and B (figs. 7 to 9) exhibited a failure of the foam core rather than along the bond line at an inclination to the loading direction (fig. 12(c) and (d)). As expected, the observed failure shear strengths, which are similar for both $\mathrm{C}$ and $\mathrm{D}$, represent the strength of the $17-4 \mathrm{PH}$ foam core. 
Table 2 compares the average values of $G$ and $\tau_{s}$ for foams with $\rho_{c} / \rho_{s} \approx 6-13 \%$. Some of these specimens were tested using the modified design shown in figure 2(c). An examination of Table 2 confirms that this design modification always resulted in the failure of the foam core (fig. 12(e) and (f)). In general, the magnitudes of the shear moduli and shear stress were significantly higher for specimens which exhibited foam core failure compared to those which failed at the brazed joints.

TABLE 2.-SHEAR MODULI AND SHEAR STRENGTHS FOR 17-4PH SANDWICHED FOAM SPECIMENS.

\begin{tabular}{|c|c|c|c|c|c|c|c|}
\hline $\begin{array}{l}\rho_{\mathrm{c}} / \rho_{\mathrm{s}} \\
(\%)\end{array}$ & $\begin{array}{c}\text { Specimen } \\
\text { design }\end{array}$ & \multicolumn{2}{|c|}{$\begin{array}{c}\mathrm{G} \\
(\mathrm{MPa})\end{array}$} & \multicolumn{2}{|c|}{$\begin{array}{c}\tau_{\mathrm{s}} \\
(\mathrm{MPa})\end{array}$} & Failure mode & Braze \\
\hline & & Average & $\begin{array}{l}\text { Standard } \\
\text { deviation }\end{array}$ & Average & $\begin{array}{l}\text { Standard } \\
\text { deviation }\end{array}$ & & \\
\hline 6 & Fig. 2(b) for A \& B & 17.5 & 1.6 & 0.82 & 0.2 & Braze joint & $\mathrm{BNi}$ \\
\hline 6 & Fig. 2(b) for $\mathrm{C} \& \mathrm{D}$ & 21.2 & 0.1 & 2.2 & 0.3 & Foam core & $\mathrm{BNi}$ \\
\hline 8 & Fig. 2(c) & 120.7 & 2.8 & 5.9 & 0.5 & Foam core & $\mathrm{BAg}$ \\
\hline 10 & Fig. 2(b) & 62.7 & 6.6 & 3.9 & 0.6 & Braze joint & BAg \\
\hline 10 & Fig. 2(c) & 203.4 & 30.3 & 7.6 & 1.8 & Foam core & BAg \\
\hline 13 & Fig. 2(b) & 52.2 & 4.3 & 5.3 & 0.7 & Braze joint & $\mathrm{BAg}$ \\
\hline 13 & Fig. 2(c) & 258.0 & 29.4 & 12.5 & 0.9 & Foam core & $\mathrm{BAg}$ \\
\hline solid & & $\begin{array}{c}77,240 \\
\text { (ref. 23) }\end{array}$ & & & & & \\
\hline
\end{tabular}

Figure 13 shows a plot of $\tau_{s}$ against $\rho_{c} / \rho_{s}$ for the 17-4PH foams. The data fall into two categories. First, the shear strengths for specimens, which exhibited foam core failure, increase with increasing values of relative densities along the trend curve given by

$$
\tau_{s} \approx 0.2\left(\frac{\rho_{c}}{\rho_{s}}\right)^{3 / 2} \sigma_{\mathrm{UTS}}
$$

where $\sigma_{\text {UTS }}=1276 \mathrm{MPa}$ (ref. 21 ) is the ultimate tensile strength of the solid wrought 17-4PH stainless steel. It is interesting to note that equations (1) and (2) are similar in form. Second, the shear strengths of specimens which failed at the brazed joints are independent of $\rho_{c} / \rho_{s}$. Significantly, the shear strengths of these specimens brazed with BAg are larger than those for samples brazed with BNi by a factor of $\sim 5.5$. 

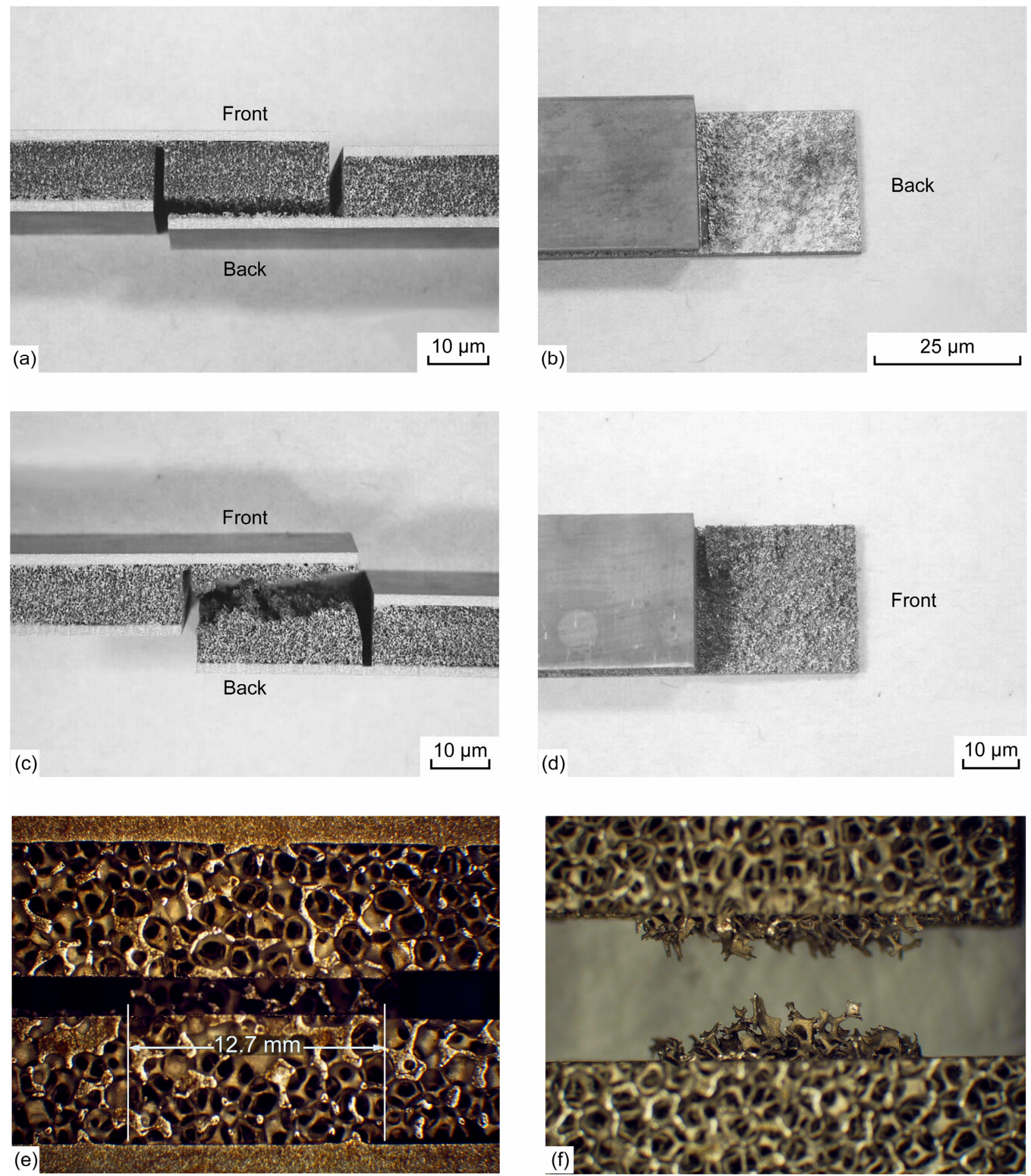

Figure 12.-(a) and (b) Optical macrographs of the side and top view, respectively, of the shear specimen A showing failure in the brazed region. (c) and (d) Optical macrographs of the side and top view, respectively, of the shear specimen $C$ showing failure in the foam core. (e) Untested and (f) tested notched shear specimen with $\rho_{c} / \rho_{s} \approx 10 \%$, where the specimen design is shown in figure 2 (c). 


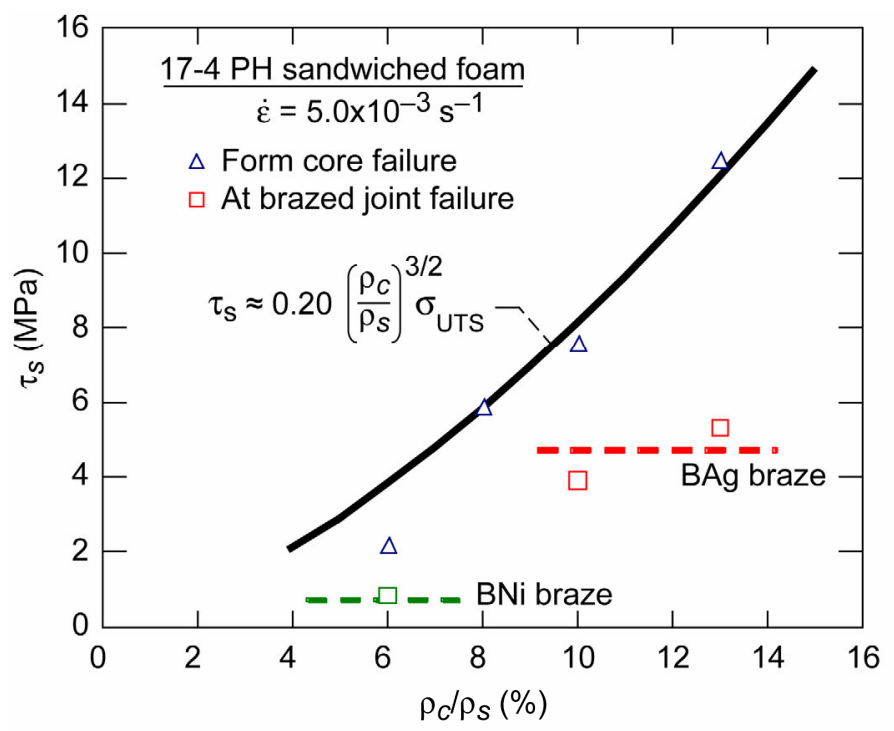

Figure 13.-Variation of shear strength of 17-4 $\mathrm{PH}$ sandwiched stainless steel foams with relative densities varying between 6 and $13 \%$. Data for specimens which failed in the form core are well described by equation. (2). Specimens that failed at thebrazed regions did not exhibit any significant variation of $\tau$ with $\rho_{c} / \rho_{s}$ but showed different shear strengths dependent on the braze alloy.

\subsection{Comparison With Theory}

Several excellent theoretical analyses exist which predict the mechanical response of ideal open cell foam sandwich panels under different loading conditions (refs. 4 to 7, and 9). Although the parameters for manufacturing the 17-4 $\mathrm{PH}$ foam cores and sandwiched foam panels remain to be optimized, it is still useful to compare their mechanical properties with predicted values to gain valuable insights on the limitations of the current processing technology. Comparison of the present results with literature data on other metal and polymeric foams, as well as with model equations derived to predict the theoretical capabilities of foam cores, is used to evaluate the fitting constants.

\subsubsection{Comparison With Literature Data}

Figures 14(a) to (c) compare the present data on 17-4PH stainless steel foams with experimental data on metallic and polymeric open cell foams compiled by Gibson and Ashby (ref. 4). Specifically, figure 14(a) shows the normalized Young's modulus, $E_{c} / E_{s}$, where $E_{c}$ and $E_{s}$ are the Young's moduli of the foam core and the solid materials, respectively. Only data obtained in the elastic deformation regimes of the stress-strain curves are shown in the figure. The magnitude of $E_{s}$ was assumed to be $196.5 \mathrm{GPa}$ (ref. 21). The solid line represents the theoretical predictions for open cell foams (ref. 4). It is evident that the magnitudes of $E_{c} / E_{s}$ for the 17-4PH stainless steel foams with $\rho_{c} / \rho_{s} \approx 6-13 \%$ fall within the limits of scatter for data on other materials. Although the overall trend line, $E_{c} / E_{s}=\left(\rho_{c} / \rho_{s}\right)^{2}$ proposed by Gibson and Ashby (ref. 4) for the other foam materials describes the present data reasonably well, the trend line, $E_{c} / E_{s}=\left(\rho_{c} / \rho_{s}\right)^{2.5}$, represented by the broken line provides a better correlation (fig. 14(a)).

Figure 14(b) plots the normalized shear modulus, $G_{c} / E_{s}$, where $G_{c}$ is the shear modulus of the foam core as a function of $\left(\rho_{c} / \rho_{s}\right)$. The figure also shows other data on polymeric foams reported elsewhere (ref. 4). The shear modulus for the wrought 17-4PH stainless steel was obtained from reference 23 . The solid line represents the regression equation, $G_{c} / E_{s}=(0.22)\left(\rho_{c} / \rho_{s}\right)^{2.1}$, which can be closely approximated 

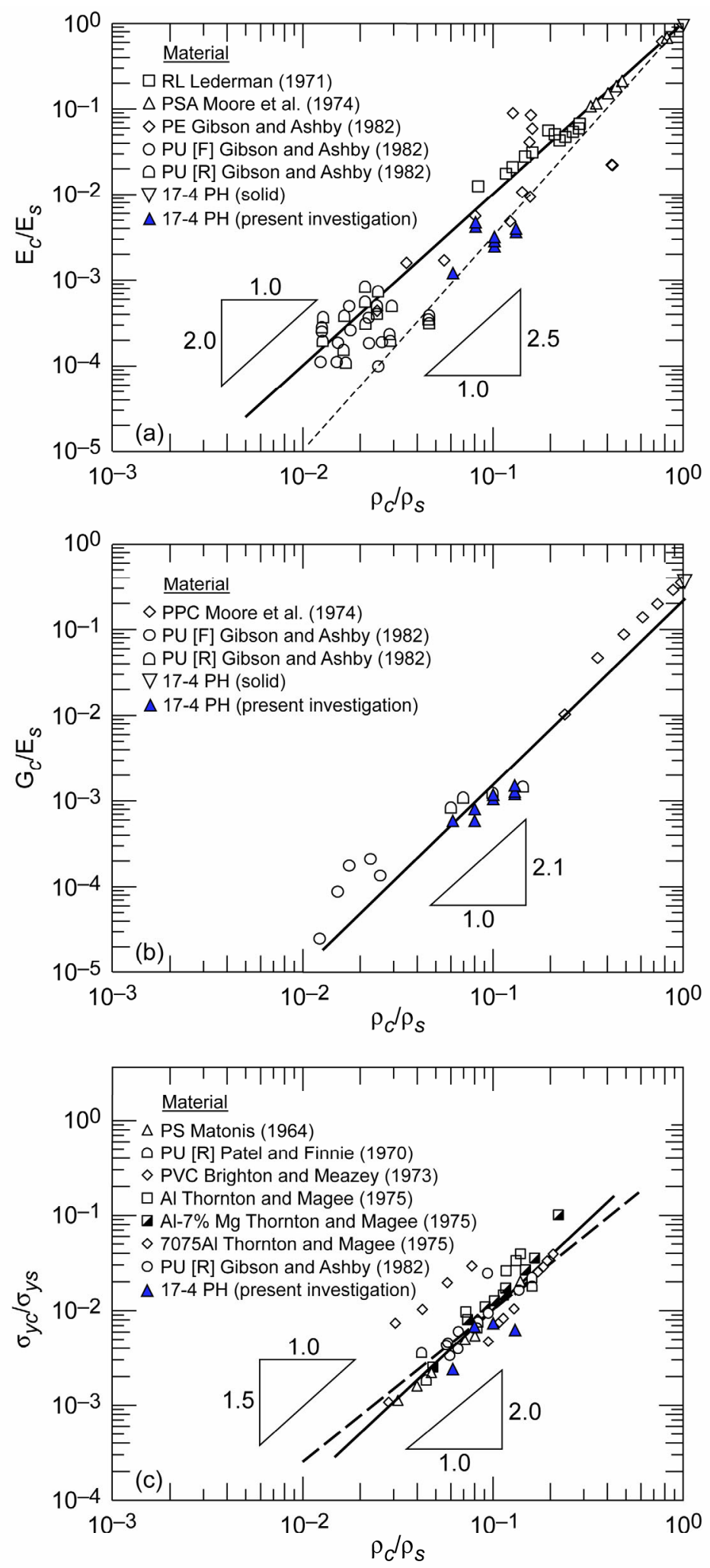

Figure 14.-Comparison of the normalized (a) Young's modulus, (b) shear modulus and (c) yield strength of the 17-4 PH stainless steel sandwiched foam with published data on other metallic and polymeric foams. The literature data and reference sources were compiled by Gibson and Ashby (ref. 4). The Young's and shear moduli data for wrought 17-4PH stainless steel were obtained from (references 21 and 23). 
by $G_{c} / E_{s} \approx(1 / 5)\left(\rho_{c} / \rho_{s}\right)^{2}$. An examination of figure 14(b) reveals that the present data on 17-4 PH stainless steel foams is in very good agreement with those for polymeric foams.

Figure 14(c) shows the magnitude of $\sigma_{y c} / \sigma_{y s}$ for the 17-4 PH stainless steel foam specimens along with similar compiled data for $\mathrm{Al}$ alloy and polymeric foams (ref. 4). The broken trend line shown in figure 14(c) corresponds to equation (1) (ref. 4). The data for the 17-4PH are reasonably close to this line and the compiled data for other materials. However, if the present data are regressed with the other data, the regression fit shown as a solid line in figure 14(c) is best described by ${ }^{3}$

$$
\frac{\sigma_{y c}}{\sigma_{y s}} \approx\left(\frac{4}{5}\right)\left(\frac{\rho_{c}}{\rho_{s}}\right)^{2}\left(R_{d}{ }^{2}=0.862\right)
$$

where $R_{d}{ }^{2}$ is the coefficient of determination. Gibson and Ashby (ref. 4) have suggested that $\left(\sigma_{y c} / \sigma_{y s}\right) \propto$ $\left(\rho_{y c} / \rho_{y s}\right)^{2}$ is the appropriate equation for elastomers and polymeric foams with $\sigma_{y s} / E_{s} \approx 1 / 30$ at very low relative density due to the possibility of elastic collapse preceding plastic collapse, but unlikely for metallic foams, where plastic collapse is expected to be dominant at all relative densities. However, the fact that the relationship $\left(\sigma_{y c} / \sigma_{y s}\right) \propto\left(\rho_{y c} / \rho_{y s}\right)^{2}$ was observed in this investigation even when the regression analyses were performed only on either the metallic or the polymeric foams suggests that it may be more universal than initially postulated.

\subsubsection{Comparison of the Compression Stress-Strain Curve With the Gibson-Ashby Equation}

The compression behavior of elastic-plastic foams, such as metallic foams, is well documented (ref. 4 and 5). The deformation of these foams consist of three stages of deformation: a linear elastic regime, a plastic collapse plateau, where the stress is almost constant with increasing strain, and a densification region, where the stress rises steeply with increasing strain at large strains as the opposing cell walls crush together compressing the cell wall material. Further deformation of the densified foam beyond $\varepsilon_{D}$ results in a stress-strain behavior almost identical to that of the solid material. Experimentally, the stress-strain response of the foam core is almost parallel to the stress axis as $E_{c}$ approaches $E_{s}$. An examination of figure 10(a) reveals that the specimens with $\rho_{c} / \rho_{s} \approx 6 \%$ were not deformed to high enough strain levels to make an accurate experimental determination of $\varepsilon_{D}$ from the stress-strain curve. Instead, $\varepsilon_{D}$ was determined by nonlinear multiple regression fitting of the stress-strain curve beyond the plastic collapse regime using the Gibson-Ashby (G-A) equation (4) (ref. 4):

$$
\begin{gathered}
\frac{\sigma_{c e}}{\sigma_{y c}}=\frac{1}{D}\left(\frac{\varepsilon_{D}}{\varepsilon_{D}-\varepsilon}\right)^{m} \text { when } \varepsilon>\varepsilon_{D}(1-1 / D) \\
\frac{\sigma_{c e}}{\sigma_{y c}}=1 \text { when } \varepsilon<\varepsilon_{D}(1-1 / D)
\end{gathered}
$$

where $D$ and $m$ are fitting constants. It should be noted that $\sigma_{y c}$ is equal to the plateau stress in the ideal situation when the stress-strain curve is parallel to the strain axis in the plastic collapse regime. In the present case, it was defined as the stress at which the elastic region and the plateau regime intersect. The elastic region was determined by drawing a line parallel to the unloading curves at $\varepsilon=0$.

\footnotetext{
${ }^{3}$ The data on the PVC foams were not considered in the regression analysis.
} 
Figure 15 compares the fitted curve with the experimental stress-strain data for specimen 2 shown in figure 10(a) for the 17-4PH foam specimen with the best defined plateau. The regressed curve describes the experimental data fairly well for values of $m=0.9, D=1.3$ and $\varepsilon_{D}=0.55$. In comparison, Gibson and Ashby (ref. 4) obtained values of $m=1.0 \pm 0.4, D=2.3$ and $\varepsilon_{D}=0.90-0.95$ for polymethacrylimid foams. Figure 16 shows the variation of $\varepsilon_{D}$ determined for the 17-4PH foam specimens for which $\rho_{c} / \rho_{s} \approx 6-13 \%$ with $\rho_{c} / \rho_{s}$ along with other data compiled on several polymeric foams (refs. 4 and 24). Although $\varepsilon_{D}$ decreases linearly with increasing $\rho_{c} / \rho_{s}$ for both sets of data, the magnitudes of $\varepsilon_{D}$ are significantly lower for the metallic foams than for the polymeric foams presumably due to the higher rigidity of the metallic cell walls. The broken line represents the regression fit to the current data ${ }^{4}$

$$
\varepsilon_{D}=0.67-1.1\left(\frac{\rho_{c}}{\rho_{s}}\right)\left(R_{d}^{2} \approx 0.530\right)
$$

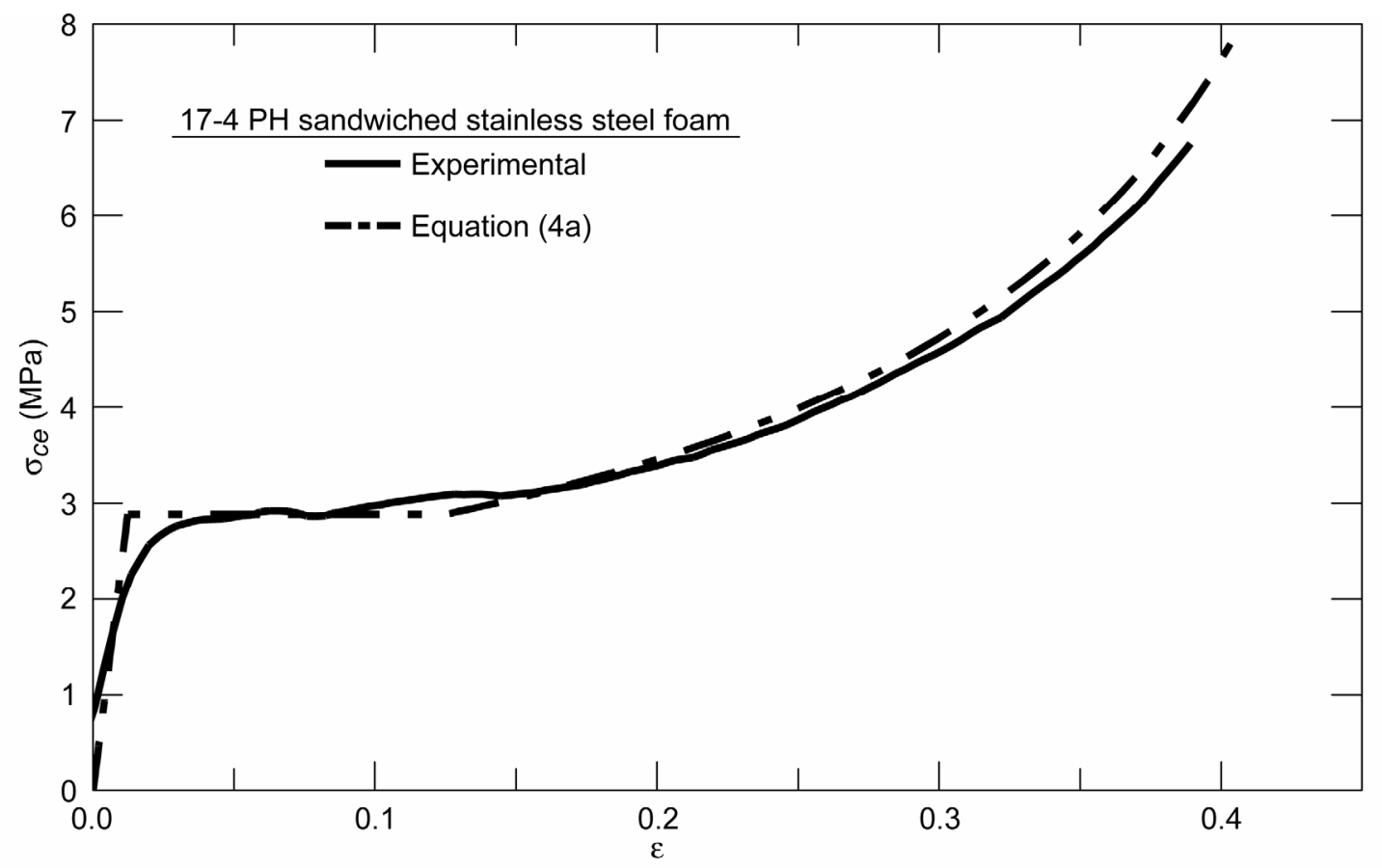

Figure 15.- Regression fit of equation (4a) to the experimental compressive stress versus compressive strain curve for 17-4 PH stainless steel sandwiched foam core for values of $D=1.3, m=0.9$ and $\varepsilon_{D}=0.55$.

${ }^{4}$ The datum point with the highest $\varepsilon_{D}$ was omitted from the regression analysis. 


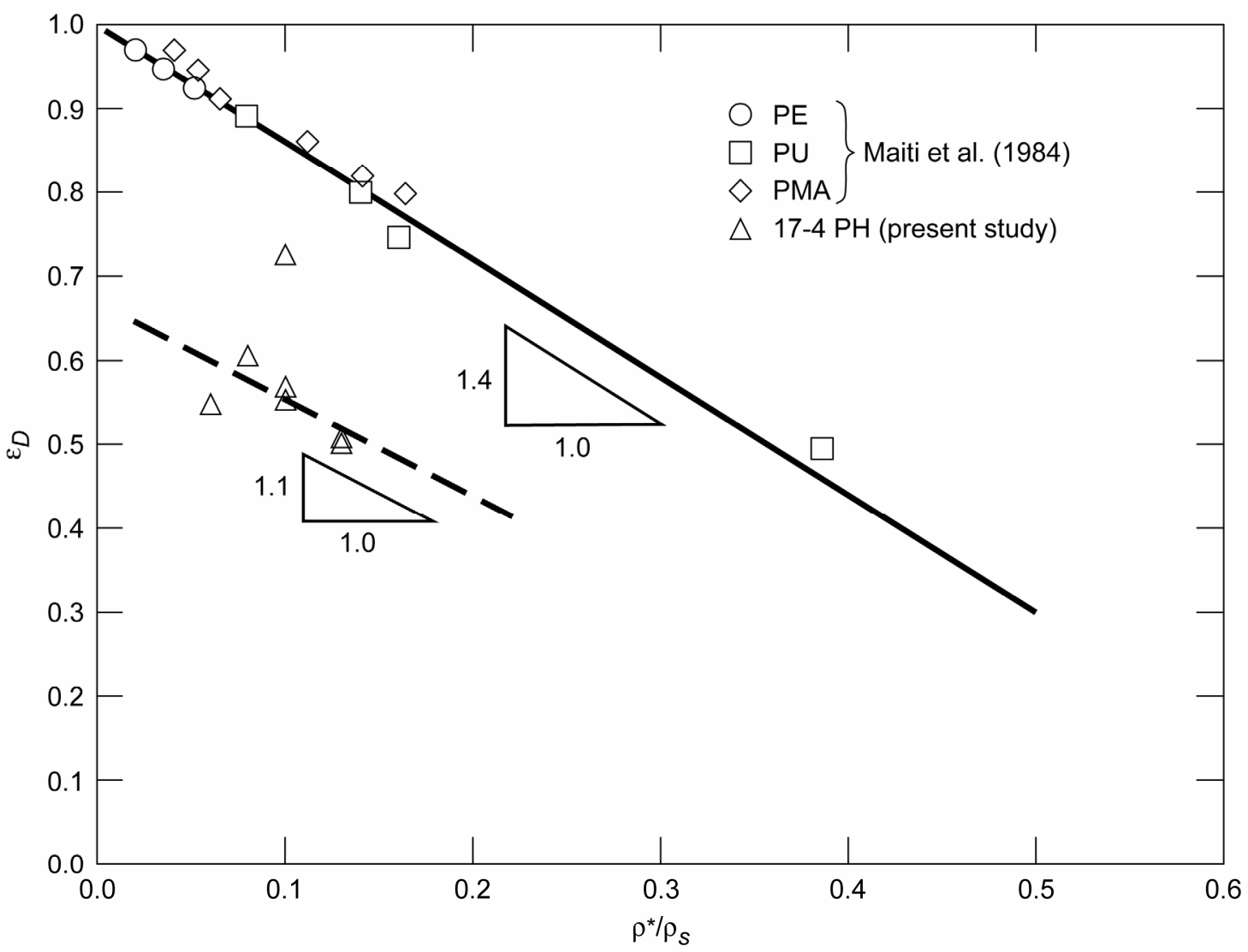

Figure 16.-Comparison of the estimated densification strain for the 17-4 PH stainless steel sandwiched foam with literature data for polymeric foams (ref. 4).

\section{Summary and Conclusions}

An innovative concept for making low cost lightweight fan blades from commercially available 17-4 PH stainless steel using sandwiched foam technology is proposed. The microstructures and mechanical properties of several rectangular sandwiched panels fabricated out of 17-4 PH stainless steel foam cores with relative densities varying between 6 and 13\% were characterized. Detailed microstructural, ultrasonic non-destructive evaluation and shear testing of the foam panels revealed that the quality of the brazed joints of the face sheets to the foam core varied from poor to good. These observations suggest a further need to optimize the processing parameters used in the manufacture of the sandwiched foam. The elastic moduli and compressive yield stresses of the 17-4 PH stainless steel foam cores were compared with published data on polymeric and metallic foams. The magnitudes of the normalized Young's modulus, $E_{c} / E_{s}$, the normalized shear modulus, $G_{c} / E_{s}$, as well as the normalized compressive yield stress, $\sigma_{y c} / \sigma_{y s}$, of the 17-4 PH stainless steel foam were comparable with the published data on other types of foams. The densification strains for the 17-4PH foams were much lower than those for polymeric foams presumably due to the higher rigidity of the cell walls. 


\section{References}

1. S. Miller, “Advanced Materials Mean Advanced Engines," Materials World, vol. 4, pp. 446-49 (1996).

2. L. Kuguoglu, G. Abumeri, and C.C. Chamis, "Durability and Damage Tolerance: Comparative Evaluation of Metallic and Composite Fan Blades," AIAA-2002-1527, 43 ${ }^{\text {rd }}$ AIAA/ASME/ASCE/ AHS/ASC Structures, Structural Dynamics and Materials Conference, Denver, CO, pp. 1-11 (2002).

3. GE Transportation press release, http://www.geae.com/aboutgeae/presscenter/ ge90/ge90 20041116.html, Evendale, OH (November 16, 2004).

4. L.J. Gibson and M.F. Ashby, Cellular Solids: Structure and Properties, Cambridge University Press, Cambridge, U.K. (1997).

5. A.G. Evans, J.W. Hutchinson and M.F. Ashby, "Multifunctionality of Cellular Metal Systems," Prog. Mater. Sci., vol. 43, pp. 171-221 (1999).

6. A.M. Harte, N.A. Fleck. and M.F. Ashby, "Sandwich Panel Design Using Aluminum Alloy Foam," Advanced Engineering Materials, vol. 2, pp. 219-222 (2000).

7. M.F. Ashby, A.G. Evans, N.A. Fleck, L.J. Gibson, J.W. Hutchinson and H.N.G. Wadley, Metal Foams: A Design Guide, Butterworth-Heinemann, Boston, MA (2000).

8. J. Banhart, "Manufacture, Characterization and Application of Cellular Metals and Metal Foams," Prog. Mater. Sci., vol. 46, pp. 559-632 (2001).

9. T.M. McCormick, R. Miller, O. Kesler. and L.J. Gibson., "Failure of Sandwich Beams with Metallic Foam Cores," Intern. J. Solids and Struct., vol. 38, pp. 4901-4920 (2001).

10. J.C. Wallach. and L.J. Gibson, "Mechanical Behavior of a Three-Dimensional Truss Material," Intern. J. Solids and Struct., vol. 38, pp. 7181-7196 (2001).

11. S.J. Mullen, "I-Beam Honeycomb Material”, U. S. Patent No. 4,632,862 (1986).

12. J.F. Newton, T.D. Martin, N. Willard, D.J. Carbery, and R. Ikegami, "Lightweight Honeycomb Panel Structure," U. S. Patent No. 5,445,861 (1995).

13. S.V. Raj, L.J. Ghosn, B.A. Lerch, M. Hebsur, L. M. Cosgriff and M. Topolski, "An Evaluation of Lightweight Stainless Steel Foam Design Concepts for Fan and Propeller Blade Applications," NASA/TM-2005-213620, Glenn Research Center, Cleveland, OH (2005).

14. Unpublished research, PORVAIR, Fuel Cell Technology Division, Hendersonville, NC, USA.

15. F.H. Froes, H. Friedrich, J. Kiese and D. Bergoint, "Titanium in the Family Automobile: The Cost Challenge," JOM, vol. 56, pp. 40-44 (2004).

16. Aerospace Materials Specification AMS 5355F, SAE International, Warrendale, PA (1995).

17. L.M. Cosgriff, B A. Lerch, M.G. Hebsur, G.Y. Baaklini and L.J. Ghosn, "Ultrasonic Spectroscopy of Stainless Steel Sandwich Panels," Proc. SAMPE 2003, Materials and Processing: Enabling Flight: Our Legacy and Future, Dayton, OH (2003).

18. J.R. Tucker, "Ultrasonic Spectroscopy for Corrosion Detection and Multiple Layer Bond Inspection," The First Joint DoD/FAA/NASA Conference on Aging Aircraft, August 1997.

19. D.W. Fitting and L. Adler, Ultrasonic Spectral Analysis for Nondestructive Evaluation, Plenum, New York (1981).

20. J. Krautkramer and H. Krautkramer, Ultrasonic Testing of Materials, Springer-Verlag, New York (1977).

21. Structural Alloy Handbook, J.M. Holt and C.Y. Ho (eds.), CINDAS, Purdue University, West Lafayette, IN (1996).

22. J. Fedor and B.A. Lerch, unpublished research, NASA Glenn Research Center, Cleveland, OH (2005).

23. Metallic Materials Properties Development and Standardization (MMPDS), Chapter 2.6.9, U. S. Department of Transportation, Knovel Library, http://www.knovel.com/knovel2/.jsp?BookID=1083\&VerticalID=0, pp. 2-195 to 2-212, (2003).

24. S.K. Maiti, L.J. Gibson and M.F. Ashby, "Deformation and Energy Diagrams for Cellular Solids," Acta Metall. vol. 32, pp. 1963-1975 (1984). 


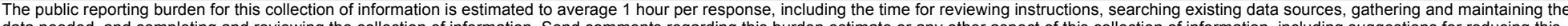

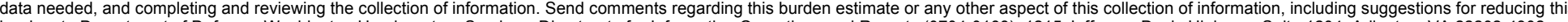

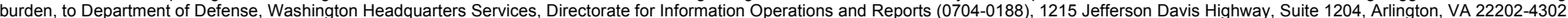

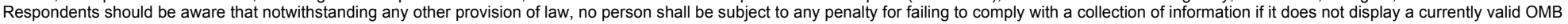
control number.

PLEASE DO NOT RETURN YOUR FORM TO THE ABOVE ADDRESS.
1. REPORT DATE (DD-MM-YYYY)
2. REPORT TYPE
3. DATES COVERED (From - To)

01-09-2007

\section{TITLE AND SUBTITLE}

Technical Memorandum

Mechanical Properties of 17-4PH Stainless Steel Foam Panels

5b. GRANT NUMBER

5c. PROGRAM ELEMENT NUMBER

6. AUTHOR(S)

Raj, S., V.; Ghosn, L., J.; Lerch, B., A.; Hebsur, M.; Cosgriff, L., M.; Fedor, J.

\section{5d. PROJECT NUMBER}

5e. TASK NUMBER

5f. WORK UNIT NUMBER

WBS 561581.02.08.03.04.03

8. PERFORMING ORGANIZATION REPORT NUMBER

E-15637

National Aeronautics and Space Administration

John H. Glenn Research Center at Lewis Field

Cleveland, Ohio 44135-3191

\section{SPONSORING/MONITORING AGENCY NAME(S) AND ADDRESS(ES)}

National Aeronautics and Space Administration

Washington, DC 20546-0001

10. SPONSORING/MONITORS
ACRONYM(S)
NASA
11. SPONSORING/MONITORING
REPORT NUMBER
NASA/TM-2007-214926

\section{DISTRIBUTION/AVAILABILITY STATEMENT}

Unclassified-Unlimited

Subject Categories: 07, 26, 05, and 01

Available electronically at http://gltrs.grc.nasa.gov

This publication is available from the NASA Center for AeroSpace Information, 301-621-0390

\section{SUPPLEMENTARY NOTES}

Published in Materials Science and Engineering A 456 (2007) 305-316.

\section{ABSTRACT}

Rectangular 17-4 PH stainless steel sandwiched foam panels were fabricated using a commercial manufacturing technique by brazing two sheets to a foam core. Microstructural observations and ultrasonic nondestructive evaluation of the panels revealed large variations in the quality of the brazed areas from one panel to the next as well as within the same panel. Shear tests conducted on specimens machined from the panels exhibited failures either in the brazed region or in the foam core for the poorly brazed and well-brazed samples, respectively. Compression tests were conducted on the foam cores to evaluate their elastic and plastic deformation behavior. These data were compared with published data on polymeric and metallic foams, and with theoretical deformation models proposed for open cell foams.

15. SUBJECT TERMS

Metal; Coatings; Space launch vehicles; Vacuum plasma spraying; NiCrAlY

\begin{tabular}{|c|c|c|c|c|}
\hline \multicolumn{3}{|c|}{ 16. SECURITY CLASSIFICATION OF: } & \multirow{2}{*}{$\begin{array}{l}\text { 17. LIMITATION OF } \\
\text { ABSTRACT } \\
\text { UU }\end{array}$} & \multirow{2}{*}{$\begin{array}{l}\text { 18. NUMBER } \\
\text { OF } \\
\text { PAGES } \\
29\end{array}$} \\
\hline $\begin{array}{l}\text { a. REPORT } \\
\mathrm{U}\end{array}$ & $\begin{array}{l}\text { b. ABSTRACT } \\
U\end{array}$ & $\begin{array}{l}\text { c. THIS } \\
\text { PAGE } \\
\text { U }\end{array}$ & & \\
\hline
\end{tabular}

19a. NAME OF RESPONSIBLE PERSON

STI Help Desk (email:help@ sti.nasa.gov) 19b. TELEPHONE NUMBER (include area code) $301-621-0390$ 

